\title{
Direct Seeded Rice: Prospects, Constraints, Opportunities and Strategies for Aerobic Rice (Oryza sativa $L$ ) in Chhattisgarh - A Review
}

\author{
S.P. Singh*, K.K. Paikra and Savita Aditya \\ Krishi Vigyan Kendra, Raigarh-496001 (C.G.), \\ Indira Gandhi Krishi Viswavidyalaya, Raipur (C.G.), India \\ *Corresponding author
}

\begin{abstract}
Keywords
Direct seeded rice,

Aerobic rice,

Greenhouse gas

emissions, Water

use efficiency,

plateauing of rice productivity

Article Info

Accepted:

15 August 2019

Available Online:

10 September 2019 water pollution, competition for water use, growing population, rising demand for food, climate change and global warming, water-intensive nature of rice cultivation and escalating labour costs have threatened the puddled transplanted rice system. The excessive utilization of natural resource bases and changing climate are leading to the negative yield trend and plateauing of rice productivity. The conservation agriculture based efficient and environmental friendly alternative management methods to increase water productivity in rice cultivation. Direct seeded rice(DSR) alternative establishment method of aerobic rice to sustain productivity of rice as well as natural resources. Aerobic rice is a projected sustainable rice production technology, which can reduce water use in rice production and produce more rice with less water. It offers certain advantages viz., less labour, less water requirement, less drudgery, early crop maturity, low production cost, proper placement of seed and fertilizer, increase fertilizer use efficiency, improve soil health for crops and less methane emission, under aerobic rice production system. However, the hurdles in achieving potential yield under aerobic system has to be overcome by focused research, then only we can make aerobic rice a potentially viable alternative to direct seeded rice (DSR). Direct seeded rice can be obtained by adopting various package and practices with scientific intervention contribute to increase the productivity and profitability of rice in Chhattisgarh state.
\end{abstract}

\section{A B S T R A C T}

Rice is commonly grown by transplanting of seedlings into puddled soil, which is not only intensive water user but also cumbersome and laborious. Looming, fresh water scarcity,

\section{Introduction}

Rice is one of the most important cereal crop in the world and staple food of the global population. Rice is indeed one of the oldest types of cereal recorded in the history of mankind. Being the major source of food after wheat, it meets 43 per cent of calorie requirement of more than two third of the Indian population. The cultivation of rice in intensive subsistence agriculture becomes synonymous with agriculture. India is the second largest producer of rice in the world being superseded only by China in the gross annual output. In South Asia, rice was cultivated on 60 million hectares ( $\mathrm{m} \mathrm{ha}$ ), and 
production was slightly above 225 million tonnes $(\mathrm{m} \mathrm{t})$ of rice, accounting for 37.5 and 32 per cent of global area and production, respectively (Mohanty, 2014). At present it is being grown on an area of about $43.39 \mathrm{~m}$ ha with the production of $104.32 \mathrm{~m} \mathrm{t}$ and average productivity of $2.4 \mathrm{t} \mathrm{ha}^{-1}$. In Chhattisgarh, it occupied $3.82 \mathrm{~m}$ ha with the production of $6.09 \mathrm{~m} \mathrm{t}$ and average productivity of $1.59 \mathrm{t}$ ha 1 (Anonymous, 2016). It shows Chhattisgarh has low productivity / ha than national level even through state is facing the scarcity of irrigation water and deterioration of soil health. Direct seeded rice (DSR) alternative establishment method of aerobic rice to sustain productivity of rice as well as natural resources. Aerobic rice is a projected sustainable rice production technology, which can reduce water use in rice production and produce more rice with less water. Direct seeded rice (DSR) is the only viable option to reduce the unproductive water flows. Direct seeded rice as a resource conservation technology which has several advantages over transplanted puddled rice system (TPR). It helps in reducing water consumption as it does away with raising of seedling in nursery, puddling and transplanting. Thus, it reduces the labour requirement to the extent of about 40 per cent and water saving up to 60 per cent from nursery raising, field preparation, seepage, percolation and evaporation losses (Singh et al., 2018). It offers certain advantages viz., less labour, less water requirement, less drudgery, early crop maturity (07-10 days), low production cost, proper placement of seed and fertilizer, increase fertilizer use efficiency, improve soil health for crops and less greenhouse gas emission, in different cropping systems (Kaur and Singh, 2017). A transformation represented by an on-going shift from conventional to conservation agriculture i.e., from an earlier set of principles based on massive soil inversion with a plough towards a new set of principles based on minimal soil disturbance, management of crop residues and innovative cropping systems is the best option of farming under rice-wheat cropping system. Recent studies indicate a slowdown in the productivity of growth in the rice-wheat systems of India (Kumar et al., 2002). Evidence from long-term experiments shows that crop yields are stagnating and sometimes declining. Current crop cultivation practices in rice-wheat systems degrade the soil and water resources thereby threatening the sustainability of the system (Gupta et al., 2003 and Ladha et al., 2003). Many innovations have contributed to the expanding use of resource conserving technologies in the country. In this regard, one of the most important technology has been introduced seed-cum-fertilizer drill which can establish crops with a minimum of soil disturbance. This seed-cum-fertilizer drill can take best advantage of residual soil moisture and thereby reduce irrigation requirements, can help in improving the timeliness of sowing, can place seed and fertilizer nutrients at suitable soil depths, and can foster the development of innovative inter-cropping systems that are particularly suitable for flood, rainfed and drought prone environments (Kumar and Ladha, 2011). The growing labor and water shortages are likely to adversely affect the productivity of the RW system (Ladha et al., 2003., Jat et al., 2009; Saharawat et al., 2009, and Gathala et al., 2011). In the changing climatic conditions, the increased night temperature at flowering stage causes spikelet sterility in rice and a reduction in yield of about $5 \%$ per degree Celsius rise above $32^{\circ} \mathrm{C}$. Therefore, conventional rice-wheat practices need future transformation to produce more food at higher income levels and reduced risk; more efficient use of land, labour, water, nutrients, and pesticides than at present; mitigation of greenhouse gas (GHG) emissions; and adaptation to climate change (Jat et al., 2011; Pathak et al., 2011, and Saharawat et al., 
2011). Suitable thermal regimes for rice and wheat crops during the annual cycle, development of short duration cultivars, irrigation, and ever-increasing demand for food were the driving forces for the expansion of rice-wheat systems during the Green Revolution. In the last few decades, high growth rates of food grain production ( 3 and $2.3 \%$ per decade, respectively, for wheat and rice) in RWC countries have kept pace with population growth (APAARI, 2000). However, evidence is emerging that the continuous rice-wheat systems are exhausting the natural resource base (Duxbury et al., 2000). Thus, the food security of the region is under continuous threat, creating new challenges in post-Green Revolution agriculture. Conservation agriculture based resource conservation technologies including new cultivars are more efficient, use less input, improve production and income, and address the emerging problems (Gupta and Seth, 2007 and Saharawat et al., 2010). Transplanted Irrigated rice requires a lot of water for puddling, transplanting and irrigation and significant water losses can occur through seepage, percolation and evaporation, it is estimated that it consumes $3000-5000$ liters of water to produce $1 \mathrm{~kg}$ of rice (Barker et al., 1998). A growing scarcity of fresh water will pose problems for rice production in future years; therefore there is a need to develop technologies that can reduce these water losses. Promising technologies include water management practices such as intermittent irrigation (e.g., alternate wetting and drying), saturated soil culture (where soil is kept between field capacity and saturation by frequent irrigation, but water is not ponded on the field) and growing rice intensively to increase the 'crop per drop' (Bouman et al., 2002). However, each of these approaches still requires prolonged periods of flooding and/or wet surface soil, and so water losses remain relatively high. International Rice Research Institute (IRRI) has coined the concept of "aerobic rice", to address the water crisis with a mission of more rice with less water. The concept of aerobic rice holds promise for farmers where water has become too scarce or expensive to grow flooded rice, and in rainfed areas where rainfall is insufficient for flooded rice production but sufficient for upland crops. Climate change as the consequence of global warming and depletion of the ozone layer is already being experienced across the world. Lowland rice cultivation is the major source of methane emissions, contributing $48 \%$ of the total green house gases emitted by agricultural sources. However, aerobic rice emits $80-85$ percent lesser methane gas into the atmosphere thus keeping the environment safe. Moreover, there is savings of water, along with labour, nutrients, and other inputs in aerobic rice compared with irrigated transplanted rice. Aerobic rice has been identified as a water saving, eco-friendly and economical technology for rice production. Aerobic rice is seen as a as a water saving, eco-friendly and economically feasible alternative to lowland rice. The resource conservation technologies involving no- or minimum-tillage with direct seeding, and bed planting, innovations in residue management to avoid straw burning, and crop diversification are being advocated as alternatives to the conventional rice-wheat system for improving productivity and sustainability (Sharma et al., 2002; Barclay, 2006, and Ladha et al., 2009). Keeping the above facts in view, the present study was carried out in farmers managed participatory approach to evaluate and validate the effects of various resource conservation technologies on productivity, resource (water, labour and energy) use efficiency, cost effectiveness and environmental impact that is, nitrogen loss, green house gases emission and biocide residue in soils. Water is undoubtedly one of the most precious natural resource; however water is becoming increasingly scarce globally. Rice production and food security 
largely depend on the irrigated lowland rice system, but whose sustainability is threatened by fresh water scarcity, water pollution and competition for water use. From the review, it is unambiguous that, aerobic rice is a potentially viable alternative to lowland rice when water scarcity is a limiting factor. Above all, adopting aerobic rice will help to minimize greenhouse gas emission rates from rice fields without affecting the productivity.

\section{Direct seeding of aerobic rice}

Direct seeding alternative establishment method of aerobic rice and relatively less water requirement compared to transplanted rice. Direct seeded rice is relatively more popular in the rainfed rice growing states like Chhattisgarh. Technological innovations have contributed to the expanding use of resource conserving technologies in the country. In this regard, one of the most important technology has been the developed and tested is low cost seed-cum-fertilizer drill which can establish crops with a minimum of soil disturbance. This seed-cum-fertilizer drill can take best advantage of residual soil moisture and thereby reduce irrigation requirements, can help in improving the timeliness of sowing, can place seed and fertilizer nutrients at suitable soil depths, and can foster the development of innovative inter-cropping systems that are particularly suitable for flood-prone and drought prone environments. There is scope to upscale the technology focused on maximizing productivity of rice in relation to promote optimizing water use efficiency. Generally, about $40 \%$ of all irrigation water goes to paddy cultivation. It is estimated that flooded rice fields produce about $10 \%$ of global methane emissions. Also, injudicious use of nitrogenous fertilizers is a common feature in paddy cultivation which is a source of nitrous oxide emissions. The current practice of excessive exploitation of ground water has led to a decline in the quality of natural resources. A transformation represented by an on-going shift from conventional to conservation agriculture ie., from an earlier set of principles based on massive soil inversion with a plough towards a new set of principles based on minimal soil disturbance, management of crop residues and innovative cropping systems is the best option of farming under rice-wheat cropping system. Recent studies indicate a slowdown in the productivity of growth in the rice-wheat systems of India (Kumar et al., 2002). Direct seeded rice avoids repeated puddling, preventing soil degradation and plough-pan formation. It facilitates timely establishment of rice and succeeding crops as crop matures 10-15 days earlier. It saves water by $35-40 \%$ and reduces production cost by Rs $3000 \mathrm{ha}^{-1}$ with an increase in yields by $10 \%$. (Singh et al., 2012). In general, a total of $1382 \mathrm{~mm}$ to $1838 \mathrm{~mm}$ water is required for the rice-wheat system accounting more than $80 \%$ for the rice growing season (Gupta et. al., 2003). It saves energy, labour, fuel and seed besides solving labor scarcity problem and reduces drudgery of labours. Several countries of Southeast Asia have been shifted from Transplanted Puddled Rice (TPR) to Direct Seeded Rice (DSR) cultivation (Pandey and Velasco, 2002). The shift in TPR to DSR is due to issues of water scarcity and expensive labour (Chan and Nor, 1993). DSR has several benefits to farmers and the environment over conventional practices of puddling and transplanting. Direct seeding helps reduce water consumption by about 30\% (0.9 million liters $\mathrm{acre}^{-1}$ ) as it eliminates raising of seedlings in a nursery, puddling, transplanting under puddled soil and maintaining 4-5 inches of water at the base of the transplanted seedlings. Direct seeding (both wet and dry), on the other hand, avoids nursery raising, seedling uprooting, puddling and transplanting, and thus reduces the labor requirement (Pepsico International, 2011). Due to avoidance of transplant injury, DSR is 
established earlier than TPR without growth delays and hastens physiological maturity and reduces vulnerability to late-season drought (Tuong, 2008). For instance, substantially higher grain yield was recorded in DSR (3.15 $\left.\mathrm{t} \mathrm{ha}{ }^{-1}\right)$ than TPR $\left(2.99 \mathrm{t} \mathrm{ha}^{-1}\right)$, which was attributed to the increased panicle number, higher 1000 kernel weight and lower sterility percentage (Sarkar et al., 2003). In addition to higher economic returns, DSR crops are faster and easier to plant, having shorter duration, less labour intensive, consume less water (Bhushan et al., 2007), conducive to mechanization (Khade et al., 1993), have less methane emissions (Wassmann et al., 2004) and hence offer an opportunity for farmers to earn from carbon credits than TPR system (Pandey and Velasco, 1999, and Balasubramanian and Hill, 2002).

\section{Seed priming}

Seed priming is the most pragmatic approaches to overcome the drought stress effects on seed. The priming process have the potential to improve emergence and stand establishment under a wide range of field conditions. These techniques can also enhance rice performance in DSR culture. It involves partial hydration to a point where germination-related metabolic processes begin but radical emergence does not occur (Farooq et al., 2006). Primed seeds usually exhibit increased germination rate, uniform and faster seedlings growth, greater germination uniformity, greater growth, dry matter accumulation, yield, harvest index and sometimes greater total germination percentage (Kaya et al., 2006). For primed seed, treatment with fungicide or insecticide should be done post-soaking to control seed borne diseases/insects. Seed can also be soaked in solution having fungicide and antibiotics for 15-20 hours (Gupta et al., 2006 and Gopal et al., 2010). Priming with imidacloprid resulted in increased plant height, root weight, dry matter production, root length, increased yield by $2.1 \mathrm{t} \mathrm{ha}^{-1}$ compared to control (non-primed), which was attributed to higher panicle numbers and more filled grains per panicle. Use of biofertilizer like Azospirillum treatment had the highest shoot:root ratio during early vegetative growth and the maximum tillers. Seed priming also reduced the need for high seeding rates. (Farooq et al., 2006).

\section{Weed management}

The major hurdle has been paucity of knowledge / awareness and contributing to high yield for weed management in direct seeded rice (DSR). Weeds are a major constraint to the success of DSR in general and to Dry-DSR in particular (Johnson and Mortimer, 2005; Singh et al., 2006 and Rao et al., 2007). Results revealed that, in the absence of effective weed control options, yield losses are greater in DSR than in transplanted rice (Baltazar and De Datta, 1992 and Rao et al., 2007). Weed reduces the economic yield $(31.5 \%)$ by competing with crop plant for nutrients, moisture, space, light. Weeds are mostly removed from the field manually in traditional method of rice cultivation. But high weed infestation is a major problem in direct-seeded rice (DSR) and causes grain yield losses up to 90 percent. Weeds are more problematic in DSR than in puddled transplanting because (1) emerging DSR seedlings are less competitive with concurrently emerging weeds and (2) the initial flush of weeds is not controlled by flooding in Wet- and Dry-DSR (Rao et al., 2007 and Kumar et al., 2008). It is important to review the weed-related issues emerging with the adoption of DSR based on the experiences from those countries where transplanting is being replaced widely by DSR. Most of the rice herbicides available have been developed for transplanted rice and these are not as effective in dry seeded rice. It 
has been observed that application of pre emergence herbicides and keeping fields submerged early in the season helps in controlling chlorosis and weeds. It has also been observed that puddling doesn't have much influence on rice yields. Gandhe (Ageratum conyzoides), Lunde (Amaranthus species), Kane (Commelina diffusa), Bhringraj (Eclipta prostrate), Jwane (Fimbristylis miliace) Dubo (Cynodon dactylon), Banso (Digitaria adcendens), Sawa (Echinochloa colona) Kade sawa (Echinochloa crusgalli), Madilo (Ischaemum rugosum), Godhe dubo (Paspalum distichum), and Sedges (Cyperus iria, Cyperus difformis) are the major weeds of direct seeded rice (Gaire et al., 2013). For high productivity of a direct-seeded crop, good and effective weed management is essential. Weed can be managed through Integrated weed management practices which includes stale seed bed techniques in which weeds are allowed to germinate by giving irrigation and then killed by nonselective herbicides two days before seeding, using mulch and subsequently killed by $2,4-\mathrm{D}$ at $30 \mathrm{DAS}$, and growing of rice varieties having greater ability to compete with weeds. However, 4050 percent reduced weed densities are reported by mulching. Various mechanical methods are also available for weed control in direct- seeded rice such as manual weeding and using hand weeder. For chemical weed control, it is necessary to select the right herbicide depending upon the weed flora, and the herbicide should be applied with proper spray techniques. Glyphosate (systemic herbicide) or paraquat (contact herbicide) can be used as pre-plant herbicide. pendimethalin, pretilachlor, butachlor, thiobencarb, oxadiazon, oxyfluorfen, and nitrofen are used as preemergence herbicides, almix and fenoxaprop are the most effective postemergence herbicide used to control the weeds of direct seeded rice. When the stalebed technique is used to establish a direct dry- seeded rice crop, pre-plant application of glyphosate followed by the pre-emergence herbicide pendimethalin and post-emergence herbicide azimsulfuron/almix can eliminate weed problems in a DSR crop, including weedy rice. However, the best result of weed control can only be seen in case of integrated weed management (Singh et al., 2005). Weeds are major constraints responsible for low productivity in direct seeded rice. DSR have indicated that pre - emergence application of pendimethalin at $1 \mathrm{~kg} \mathrm{ha}^{-1}$ dissolved in 500-600 L of water followed by post emergence application of ready mix of chlorimuron + metsulfuron @ $4 \mathrm{~g} \mathrm{ha}^{-1}$ for broad leaved and sedges weed control or ethoxysulfuron@15 $\mathrm{g} \mathrm{ha}^{-1}$ for sedges and broad leaved weeds, or 2,4-D at $500 \mathrm{~g} \mathrm{ha}^{-1}$ applied around 20 days after sowing for broad leaved weeds and Fenoxaprop @ $50 \mathrm{~g} \mathrm{ha}^{-1}$ for grassy weeds have been found effective in realizing higher rice grain yield. Azimsulfuron is also performing well in controlling complex weed flora in DSR (Pathak et al., 2011). This would assist in developing effective and economically viable medium- to long-term sustainable weed control strategies. This section reviews some of the weed related issues that have emerged in countries where DSR is widely practiced. The practice of direct seeding on large scale increased herbicide use for weed management in aerobic rice, which slowly resulted in the appearance of resistance in weed against certain herbicides. Therefore, the first case of herbicide resistance was reported in F.miliacea against 2,4-D in 1989 in Malaysia. But, later on, the number of resistant weed biotypes to different herbicides increased to 10. In, Thailand, Korea and Philippines, the number of herbicide-resistance cases in weeds increased from zero before DSR introduction to 5, 10 and 3, respectively, after its introduction (Kumar and Ladha, 2011). Weeds are the most important constraint to the success of DSR in general and to Dry- 
DSR in particular (Singh et al., 2006 and Rao et al., 2007). The weeds pose to be more problematic in DSR than puddle transplanting because (1) The emerging weeds are more competitive as compared to the simultaneously emerging DSR seeding and (2) lack of water layer in Wet-DSR makes these crops more prone to initial weed infestation which lacks otherwise in case of transplanting (Rao et al., 2007 and Kumar et al., 2008). The revealed that, in the absence of effective weed control opinions, yield losses are greater in DSR than in transplanted rice. The reported range of such yield losses in DSR in India is 20-85\% (Rao et al., 2007). Weedy rice/ red rice (O. Sativa, $F$. spontanea), has emerged as a serious concern to rice production in areas where direct seeding especially Dry-DSR widely replaces CT-PTR.

Weeds in rice are highly efficient and causes severe rice yield losses ranging from 15100\% (Kumar and Ladha, 2011). Milling quality is also impaired if weedy rice gets mixed with rice seeds during harvesting (Ottis et al., 2005). Weedy rice is difficult to control because of its genetic, morphological and phonological similarities which rice. Selective control of weedy rice was never achieved at a satisfactory level with herbicides (Noldin et al., 1999). In Malaysia, proper land preparation along with the stale seedbed technique using nonselective herbicides before planting rice has been recommended to reduce the density of weedy rice (Karim et al., 2004). Recommends an integrated approach that combines preventive and chemical methods (FAO, 1999).

The important factors for control and to avoid further infestation are to use clean and certified seeds (Rao et al., 2007). Herbicide resistant rice technologies offer for selective control of weedy rice but the risk of gene flow from herbicide resistant rice to weedy rice poses a constraint for the long-term utility of this technology (Kumar et al., 2008). There is need to develop effective management strategies for keeping weedy rice under check.

\section{Precise water use efficiency}

Precise water use efficiency, particularly during crop emergence phase is crucial in direct seeded rice (Balasubramanian and Hill, 2002). From sowing to emergence, the soil should be kept moist but not saturated to avoid seed rotting. After sowing in dry soil, applying a flush irrigation to wet the soil if it is unlikely to rain followed by saturating the field at the three leaf stage is essential (Bouman et al., 2007). There are few reports evaluating mulching for rice, apart from those from China, where 20-90\% input water savings and weed suppression occurred with plastic and straw mulches in combination with DSR compared with continuously flooded TPR. Bund management also plays an important role in maintaining uniform water depth and limiting water losses via seepage and leakage (Humphreys et al., 2010). Some researchers (Gupta et al., 2006) have recommended avoiding water stress and keeping the soil wet at the following stages: tillering, panicle initiation, and grain filling. Water stress at the time of anthesis results in maximum panicle sterility. Research showed that $33-53 \%$ irrigation water can be saved in Dry-DSR with AWD as compared with conventional tilled-transplanted puddled rice (CT-TPR) without compromising grain yield (Joshi et al., 2013). Conventional transplanted rice with continuous standing water has relatively high water inputs and low water productivity as compared to other technologies of rice cultivation. Reports from on-farm experiments to reduce water input by water saving irrigation techniques and alternative crop establishment methods, in the Philippines reported that with continuous standing water, direct wet-seeded rice yielded 
higher than traditional transplanted rice by 3 $17 \%$, required $19 \%$ less water during the crop growth period and increased water productivity by $25-48 \%$. Rice can be established by DSR once $150 \mathrm{~mm}$ rain or irrigation water has accumulated compared to $450 \mathrm{~mm}$ needed for transplanting. Furthermore, because DSR establishes deeper roots and is more efficient at using soil moisture, less frequent irrigation is required during the growing season. Water saving of $35-55 \%$ have been reported for dry seeded rice sown into non-puddled soil with the soil kept near saturation or field capacity compared with continuously flooded $(\sim 5 \mathrm{~cm})$ transplanted rice in research experiments in north west India (Lav Bhushan et al., 2007). In some other studies the DSR crop saved $32 \%$ water compared to transplanted rice without any yield penalty. The productivity of water in conventional rice cultivation needs 3000 to $5000 \mathrm{~L}$ of water to produce $1 \mathrm{~kg}$ rice. At global level $70-80 \%$ of fresh water is used in agriculture and rice accounts for $85 \%$ of this water. Rice's large water demand is expected to outstrip the available supply in the near future. The declining availability and quality of water, increased competition from domestic and industrial sectors, and increasing costs are already affecting the sustainability of irrigated rice production systems in many parts of South Asia. For example, in the upper transect of the IGP, rice cultivation resulted in a decline in water tables and water quality. Many districts in the rice-wheat growing area of Haryana, India, show a water table decline in the range of 3 $10 \mathrm{~m}$ over the last two decades. The groundwater table has fallen at about $23 \mathrm{~cm}$ yr-1 in the Central Punjab, India. Excess pumping depletes ground water and causes pollution such as arsenic contamination as has been observed in many parts of West Bengal. Water application in rice production, therefore, needs to be decreased by increased water-use efficiency through reduced losses caused by seepage, percolation, and evaporation; laser land leveling; crack ploughing to reduce bypass flow; and bund maintenance. The direct seeded rice has got potential to improve the efficiency of water use. Aerobic rice is a new practice of cultivating rice that requires less water than lowland rice. The conventional transplanting method of rice used higher quantity of water $\left(16,200 \mathrm{~m}^{3} \mathrm{ha}^{-1}\right)$ whereas aerobic rice used minimum quantity $\left(9,687 \mathrm{~m}^{3} \mathrm{ha}^{-1}\right)$ and observed a water saving of 32.9 to 43.9 per cent over transplanted rice (Geethalakshmi et al., 2009). According to Belder et al., (2005) water requirement was less in aerobic rice (842 and $940 \mathrm{~mm}$ ) as compared to flooded rice (1233 and $1473 \mathrm{~mm}$ ) in 2002 and 2003. Aerobic way of growing rice saves water by eliminating continuous seepage, percolation and by reducing reducing evaporation (Castaneda et al., 2002). Flooded rice used three times more irrigation water $(358 \mathrm{~mm})$ than aerobic rice $(89 \mathrm{~mm})$ for land preparation and twice during the crop growth period (1148 and $481 \mathrm{~mm})$. In aerobic rice production system, continuous seepage, percolation and evaporation losses are greatly reduced; it effectively utilizes the rainfall and help in enhancing the water productivity (Bouman et al., 2005). Kadiyala et al., (2012) reported that the total amount of water applied (including rainfall) in the aerobic plots was 967 and $645 \mathrm{~mm}$ compared to 1546 and 1181 $\mathrm{mm}$ in flooded rice system, during 2009 and 2010 , respectively. This resulted in 37 to $45 \%$ water savings with the aerobic method. Bouman et al., (2002) estimated water requirement for aerobic condition by growing two elite aerobic rice genotypes and one popular lowland variety both under flooded and aerobic conditions. The results of their study has shown that compared with lowland rice, water inputs in aerobic rice were more than 50\% lower (only $470 \mathrm{~mm}-650 \mathrm{~mm}$ ), water productivities $64 \%-88 \%$ higher, and labour use 55\% lower. The lower water input, 
kept at field capacity in direct seeded rice reduced the rates of evapo-transpiration (22$31 \%$ ) and percolation (22-38\%) as compared to traditional system (Chaudhary et al., 2008). The direct seeded aerobic rice is a typical technology, wherein an additional 130-150 $\mathrm{mm}$ of water input can be saved by foregoing the wet land preparation (Bouman et al., 2005). In experiments at Japan by Kato et al., (2006) in aerobic fields, the total amount of water supplied (irrigation plus rainfall) was $800-1300 \mathrm{~mm}$. The aerobic rice cultivation saves 40-50 per cent of water with marginal reduction in grain yield of about 10-20 per cent (Singh and Chinnuswamy, 2006). Wang et al., (2002) reported that in aerobic rice, water use was 60 per cent less than that of flooded rice, requires less labour (55 per cent) and it facilitates mechanization also. Patel et al., (2010) reported the higher WUE of aerobic rice compared to flooded condition, similar results were also given by Singh et al., (2008). Jinsy et al., (2015) found that compared to conventional flooded rice, the average water productivity of aerobic rice $(0.68 \mathrm{~kg} \mathrm{~m} 3)$ was 60.7 per cent higher. Gill et $a l$. , (2006) reported that the irrigation water productivity of rice on beds and furrow system was significantly higher $\left(0.69 \mathrm{~g} \mathrm{~kg}^{-1}\right)$ than that of paddy raised on puddled flat plots. According to water productivity in direct seeded rice was 0.34 and $0.76 \mathrm{~kg}$ grain $\mathrm{m}^{-3}$ in 2002 and 2003, respectively. According to Wang et al., (2002) total water productivity of aerobic rice was 1.6 to 1.9 times higher and water use about 60 per cent less than lowland rice. Reddy et al., (2010) reported that water productivity was higher under aerobic $\left(0.20\right.$ to $0.60 \mathrm{~kg} \mathrm{~m}^{-3}$ of water $)$ than that under transplanted $(0.14$ to $0.43 \mathrm{~kg}$ $\mathrm{m}^{-3}$ of water) condition. Under aerobic conditions, the WUE of aerobic rice cultivars was higher $\left(0.650 .83 \mathrm{~g}_{\text {grain } \mathrm{kg}^{-1}}\right.$ water for HD 502) compared to the WUE of lowland cultivar JD 305, which was 0.26 to $0.66 \mathrm{~g}$ grain $\mathrm{kg}^{-1}$ water Reddy et al., (2010)
According to Bouman et al., (2002) experiments on aerobic rice have shown that water inputs were more than 50 per cent lesser (only 470-650 $\mathrm{mm}$ ) and water productivities were 64-88 per cent higher than the lowland rice. From the pertinent literature available, it could be concluded that rice can be grown under aerobic conditions like any other upland crop by developing different agro practices like nutrient management, irrigation methods and schedules for reaping a bountiful yield while saving water. The water use efficiencies of aerobic varieties under aerobic conditions were 164-188 per cent higher than that of lowland varieties under lowland conditions (Wang and Tang, 2000). Aerobic rice could be successfully cultivated with $600-700 \mathrm{~mm}$ of total water in summer and entirely on rainfall in wet season (Sritharan et al., 2010). Field experiments were conducted in clay loam soils with five rice production systems indicated that the water saving through semi-dry rice with rotational irrigation was $20 \%$ with a water use efficiency of $6.1 \mathrm{~kg} \mathrm{ha}^{-1} \mathrm{~mm}^{-1}$ compared to farmers practice of transplanting with continuous flooding $\left(5.2 \mathrm{~kg} \mathrm{ha}^{-1} \mathrm{~mm}^{-1}\right)$.

\section{Nutrients management}

Precision land levelling not only improves water productivity but also the fertilizer use efficiency, especially $\mathrm{N}$ fertilizers (Jat et al., 2006). In conventional well-tilled situations, half of the $\mathrm{N}$ is applied as basal and the balance is top-dressed. Results of on farm and station trials have shown that delaying the bulk of the $\mathrm{N}$ application to around the first node/ stem elongation or later results in better yield (Sayre et al., 2005). In South Asia, the general practice is to apply half of the $\mathrm{N}$ as basal with the balance top dressed in two equal splits, 40-45 and 60-70 days after sowing. Gupta et al., (2003) observed that early wheat planting with zero till and split application of $\mathrm{N}$ or single deep band 
placement of $\mathrm{N}$ along with the seed or between the seed rows had insignificant differences on wheat yield under the different treatments. It has been reported that needbased $\mathrm{N}$ management through use of leaf colour charts, shade 4, and a Soil Plant Analysis Development (SPAD) value of 42 reduces the $\mathrm{N}$ requirement by $12.5-25 \%$ without any reduction in yield in the ricewheat system (Singh et al., 2002 and Shukla et al., 2004).

Sayre et al., (2005) reported that in minimum till or permanent bed situations, where soil is not tilled to incorporate the basal $\mathrm{N}$ fertilizer but is banded, the differences related to timing of $\mathrm{N}$ application are not as clear for either yield or grain protein content. Thus not tilling while maintaining residues on the soil surface, together with basal application of $\mathrm{N}$ fertilizer to keep the fertilizer and residues separated, appears to change the soil $\mathrm{N}$ dynamics. Residues present on the soil surface interfere with the movement of top-dressed $\mathrm{N}$ reaching the root zone and therefore banding at planting time is more efficient. When nitrogen was applied in three splits in zero till wheat, total $\mathrm{N}$ uptake $\left(144.6 \mathrm{~kg} \mathrm{ha}^{-1}\right)$ was lower than corresponding conventionally tilled wheat (184.4 $\mathrm{kg} \mathrm{ha}^{-1}$ ) with crop residues removed (Pasricha et al., 2006). Surface retention of residues seems to immobilize $\mathrm{N}$ when topdressed and affects the decomposition rates of crop residues due to altered soil temperature and moisture regimes. Straw management is important as a strategy for replenishing $\mathrm{K}$ in micaceous soils, which have not been fertilized for a long period. In these soils the rate of $\mathrm{K}$ release is primarily dependent on the amount of biotitic micas only (Pal et al., 2005). These soils release enough $K$ to meet demands of early rice in semiarid climatic conditions, but not of the intensive rice-wheat system practiced in sub-humid environments. Straw management seems to slow down the rapid vermiculitization of biotitic mica and therefore, fixation of $\mathrm{K}^{+}$and $\mathrm{NH}_{4}^{+}$from the applied nitrogenous fertilizers. General recommendations for NPK fertilizers are similar to those in puddled transplanted rice, except that a slightly higher dose of N (22.5$30 \mathrm{~kg} \mathrm{ha}^{-1}$ ) is suggested in DSR (Dingkuhn et al., 1991 and Gathala et al., 2011). This is to compensate for the higher losses and lower availability of $\mathrm{N}$ from soil mineralization at the early stage as well as the longer duration of the crop in the main field in Dry-DSR. Early studies conducted in Korea indicated that $40-50 \%$ more $\mathrm{N}$ fertilizer should be applied in Dry-DSR than in CT-TPR (Park et al., 1990 and Yun et al., 1993), although higher $\mathrm{N}$ application also leads to disease susceptibility and crop lodging. The general recommendation is to apply a full dose of $\mathrm{P}$ and $\mathrm{K}$ and one-third $\mathrm{N}$ as basal at the time of sowing using a seed-cum-fertilizer drill/planter. This allows placement of the fertilizer just below the seeds and hence improves fertilizer efficiency. Split applications of $\mathrm{N}$ are necessary to maximize grain yield and to reduce $\mathrm{N}$ losses and increase $\mathrm{N}$ uptake. Split applications ensure a supply of $\mathrm{N}$ to match crop demand at the critical growth stages. The remaining twothird dose of $\mathrm{N}$ should be applied as topdressing in equal parts at active tillering and panicle initiation stage. In addition, $\mathrm{N}$ can be managed using a leaf colour chart (LCC) (Shukla et al., 2004 and Alam et al., 2005). In the fixed-time option, $\mathrm{N}$ is applied at a preset timing of active tillering and panicle initiation, and the dose can be adjusted upward or downward based on leaf colour chart. In the real-time option, farmers monitor the color of rice leaves at regular intervals of 7-10 days from early tillering (20 DAS) and $\mathrm{N}$ is applied whenever the colour is below a critical threshold value (IRRI, 2010). For high-yielding inbreds and hybrids, $\mathrm{N}$ application should be based on a critical LCC value of 4 , whereas, for basmati types, $\mathrm{N}$ should be applied at a critical value of 3 (Shukla et al., 2004; Gupta et al., 2006 and 
Gopal et al., 2010). Since more $\mathrm{N}$ is applied in Dry-DSR and losses are higher than in CTTPR, more efficient $\mathrm{N}$ management for DryDSR is needed. Slow-release (SRF) or controlled-release $\mathrm{N}$ fertilizers (CRFs) offer the advantage of a "one-shot dose" of $\mathrm{N}$ and the option to reduce $\mathrm{N}$ losses because of their delayed release pattern, which may better match crop demand (Shoji et al., 2001). Oneshot application will also reduce labor cost. Fashola et al., (2002) reported that CRF improves $\mathrm{N}$ use efficiency and yield compared with untreated urea. Because of these benefits, CRF with polymer-coated urea is used by Japanese farmers in ZT-dry-DSR (Ando et al., 2000 and Saigusa, 2005). Despite these benefits, farmers' use of CRF is limited mainly because of the high costs associated with it. The cost of CRF may be four to eight times higher than that of conventional fertilizers (Shaviv and Mikkelsen, 1993). In addition, published results on the performance of SRFs/CRFs compared with conventional fertilizers are not consistent. Christianson and Schultz (1991), Stutterheim et al., (1994), and Fashola et al., (2002) have demonstrated higher $\mathrm{N}$ use efficiency through the use of CRFs. Saigusa (2005) reported higher $\mathrm{N}$ recovery of co-situs (placement of both fertilizer and seeds or roots at the same site) application of CRF with polyolefin-coated ureas of 100-day type (POCU-100) than conventional ammonium sulfate fertilizer applied as basal and topdressed in zero-till direct-seeded rice in Japan. In contrast, Wilson et al., (1990), Wells and Norman (1992), and Golden et al., (2009) reported inferior performance of SRF or CRF compared with conventional urea topdressed immediately before permanent flood establishment. Split application of K has also been suggested for direct seeding in medium-textured soil (PhilRice, 2002). In these soils, $\mathrm{K}$ can be split, with $50 \%$ as basal and $50 \%$ at early panicle initiation stage. Deficiency of $\mathrm{Zn}$ and $\mathrm{Fe}$ is more common in aerobic/non-flooded rice systems than in flooded rice systems (Sharma et al., 2002; Singh et al., 2002; Choudhury et al., 2007; Pal et al., 2008 and Yadvinder-Singh et al., 2008). Therefore, micronutrient management is critical in Dry-DSR. To avoid zinc deficiency, 25-50 kg ha ${ }^{-1}$ zinc sulfate is recommended (Anonymous, 2008 and 2010). Basal application of zinc to the soil is found to be the best. However, if a basal application is missed, the deficiency can be corrected by topdressing up to 45 days (Anonymous, 2010). Zinc can be supplied by foliar application $(0.5 \%$ zinc sulfate $)$ two to three times at intervals of 7-15 days just after the appearance of deficiency symptoms. For iron, it has been observed that foliar application is superior to soil application (Datta et al., 2003 and Anonymous, 2010). Foliar-applied Fe is easily translocated acropetally and even retranslocated basipetally. A total of $9 \mathrm{~kg} \mathrm{Fe}$ $\mathrm{ha}^{-1}$ in three splits $(40,60$, and 75 DAS) as foliar application $\left(3 \%\right.$ of $\mathrm{FeSO}_{4} \cdot 7 \mathrm{H}_{2} \mathrm{O}$ solution) has been found to be effective (Pal et al., 2008). Farmers fertilizer application varied from 130-160 kg N, 0-60 kg of Phosphorus (P) and 0-60 kg potassium (K) $\mathrm{ha}^{-1}$ in rice and $140-190 \mathrm{~kg} \mathrm{~N}, 0-50 \mathrm{~kg} \mathrm{P}$ and $0-60 \mathrm{~kg} \mathrm{~K} \mathrm{ha}^{-1}$ in wheat in all the practices. While K was broadcasted for rice, N (80\% of the total quantity) and whole of $\mathrm{P}$ was placed at $10-\mathrm{cm}$ depth using no-till seed-cumfertilizer drill at the time of seeding in DSR. In transplanted rice $\mathrm{N}(80 \%$ of the total quantity) and whole of $\mathrm{P}, \mathrm{K}$ fertilizers were broadcasted by some farmers before transplanting. Extra dose of $\mathrm{N}$ was applied on the basis of leaf colour chart (LCC) as described by Shukla et al., (2004). For wheat, all the fertilizers were applied basally using no-till seed-cum-fertilizer drill Fertilizer, especially nitrogen fertilizer, is often applied in excess of the crop requirement and at inappropriate times in many intensively irrigated rice systems, which increases the risk of poor fertilizer recovery by the rice 
crop. Less than $35 \%$ of applied nitrogen $(\mathrm{N})$ is taken up by rice and the remaining $65 \%$ is lost from soil-plant systems into the environment through volatilization, denitrification, leaching, and runoff, thus creating pollution problems (Ladha et al., 2005). The main loss pathways are (1) leaching, predominantly nitrate $\left(\mathrm{NO}_{3}{ }^{-}\right)$but also occasionally ammonium, and soluble organic $\mathrm{N}$; (2) denitrification, resulting in emissions of nitrous oxide $\left(\mathrm{N}_{2} \mathrm{O}\right)$, nitric oxide $(\mathrm{NO})$, and dinitrogen $\left(\mathrm{N}_{2}\right)$ gases; and (3) ammonia $\left(\mathrm{NH}_{3}\right)$ volatilization. Significant improvement in $\mathrm{N}$ use efficiency (NUE) is therefore crucial and can be made by adopting fertilizer, soil, water, and crop management practices that will maximize crop $\mathrm{N}$ uptake, minimize $\mathrm{N}$ losses, and optimize indigenous soil $\mathrm{N}$ supply. The key to improve NUE is the synchrony between $\mathrm{N}$ supply and demand. Nutrient dynamics altogether varies in both DSR and PTR systems mainly because of the difference in land preparation and water management techniques. In case of DSR, soil remains aerobic because of dry land preparation as compared to PTR where soil is kept flooded and is puddled. Puddling has positive impact on weed control (Sahid and Hossain, 1995) and nutrient availability (Wade et al., 1998). In submerged conditions, less oxygen in the rhizosphere prevent oxidation of $\mathrm{NH}_{4}{ }^{+}$and thus reduce leaching, (Kreye et al., 2009) increase availability of $\mathrm{P}$ (Neue and Bloom, 1987) as well as Fe (Pandey et al.,1985). Deficiency of micro nutrients are major concern in DSR. A shift from PTR to DSR affect $\mathrm{Zn}$ availability to rice (Gao et al., 2006) and it reduces because of reduced release of $\mathrm{Zn}$ from highly insoluble fractions in aerobic rice field (Kirk and Bajita,1995). Zn deficiency is caused by high $\mathrm{pH}$, high carbonate content (Mandal et al., 2000) and more bicarbonate in calcareous soil (Forno et al.,1975) which immobilize $\mathrm{Zn}$ because of inhibition effect (Dogar and Hai, 1980). Availability of $\mathrm{P}$ and $\mathrm{Zn}$ increases when $\mathrm{pH}$ is below neutral in the rhizosphere (Kirk and Bajita,1995) because of their increased solubility (Saleque and Kirk, 1995). Zn uptake by DSR is also affected by source as well as time of $\mathrm{Zn}$ application (Giordano and Mortvedt, 1972).

\section{Diseases, insects and pests management}

Generally, direct seeded rice is relatively more susceptible to similar diseases, insects and pests than conventional transplanted rice; however, under some conditions there may be greater chance of outbreak of insect-pests and diseases in DSR with high rice plant densities. In wet-seeded rice, rats are big problems to crop establishment and it is susceptible to various diseases, rice blast being one of the evastating diseases, in both aerobic and direct-seeded cultures (Bonman and Leung, 2004). Water deficit and shift from transplanting to direct seeding favours neck blast spread (Kim, 1987). Sometimes the attack of arthropod insect pests is reduced in DSR compared with TPR (Oyediran and Heinrichs, 2001), but a higher frequency of sheath blight and dirty panicle have been observed in DSR (Pongprasert, 1995). Direct seeded rice is susceptible to various disease and rice blast is one of the most common (Bonman and Leung, 2004) and damage due to rice blast increases under water stress conditions (Bonman, 1992), since the water level affects several process such as liberation and germination of spores and infection in rice causing blast (Kim,1987). The crop microclimate especially dew deposition is affected by water management which makes the environment congenial for host susceptibility (Savary, 2005 and Sah and Bonman, 2008). The change in the crop physiology as influenced by water management also triggers host susceptibility (Bonman, 1992). In DSR, the other disease and insect problems reported are sheath blight and dirty panicle (Pongprasert, 1995), brown spot disease and plant hoppers (Savary, 2005) 
and soil borne pathogenic fungus (Gaeumannomyces graminis var. graminis) in dry- seeded rice in Brazil without additional irrigation (Prabhu et al., 2002). For poor Asian farmers use of natural plant derived biocides, such as, those from neem (Azadirachta indica) as it is cheaper, indigenously available and eco-friendly product. Also pathogens cannot easily develop resistance against neem products because the more than one molecule responsible for biocidal activity. Neem products have been reported to have fungicidal, insecticidal and nematicidal, and antiviral properties (Prasad, 2007). Cultivation of resistant crop varieties and summer ploughing is the pre requisite for efficient management of viral and other diseases/pests. Optimum rate of nitrogenous fertilizers avoid the incidence of brown plant hopper and blast attack. Fumigating the rat burrows with cow dung cake keeping the cow dung balls soaked in kerosene all over the field results in better control of rats and other borrowing animals. Root- knot nematodes pose a severe constraint when shift from PTR to DSR takes place (Prot et al., 1994). Root knot nematode, Meloidogyne graminicola was first reported in 1963 from the Louisiana state university, Baton Rouge, USA. In a study in Philippines, RKNs were found to be most damaging pathogen for aerobic rice Apo (Prasad, 2011). Rice yield in untreated plots was $0.2-0.3 \mathrm{t} \mathrm{ha}^{-1}$ in 2006. However, in plots treated with nematicide dazomet yield of $2.2 \mathrm{t}$ $\mathrm{ha}^{-1}$ was obtained in 2006 and $2.4 \mathrm{t} \mathrm{ha}^{-1}$ in 2007. In the first year, degree of galling in rice root was only 0.4 in the nematicidetreated plots, whereas, it was $3.4-4.4$ in untreated plots. In 2007, galling increased even in nematicide - treated plots to 2.4, where, it was $4.8-4.9$ in untreated plots.

\section{Emission of greenhouse gas (GHGs)}

Direct seeding of aerobic rice can help in reducing $\mathrm{CH}_{4}$ emissions, but aerobic soil condition can also increase $\mathrm{N}_{2} \mathrm{O}$ emissions. Agricultural practices play an important role in the emissions of carbon dioxide $\left(\mathrm{CO}_{2}\right)$, methane $\left(\mathrm{CH}_{4}\right)$, and nitrous oxide $\left(\mathrm{N}_{2} \mathrm{O}\right)-$ these three GHGs contribute to global warming. Agriculture's share in the total emissions of $\mathrm{N}_{2} \mathrm{O}, \mathrm{CH}_{4}$, and $\mathrm{CO}_{2}$ are $60 \%$, $39 \%$, and $1 \%$, respectively (OECD, 2000), with rice-based cropping systems playing a major role. Rice production systems impact global warming potential (GWP) primarily through effects on methane, but $\mathrm{N}_{2} \mathrm{O}$ and $\mathrm{CO}_{2}$ effects can also be important in some systems. The GWP of $\mathrm{CH}_{4}$ and $\mathrm{N}_{2} \mathrm{O}$ is 25 and 298 times higher than that of $\mathrm{CO}_{2}$ (IPCC, 2007). GHG emissions, especially $\mathrm{CO}_{2}$ and $\mathrm{CH}_{4}$ from rice fields, are large and very sensitive to management practices. Therefore, rice is an important target for mitigating GHG emissions (Wassmann et al., 2004). Flooded rice culture with puddling and transplanting is considered one of the major sources of $\mathrm{CH}_{4}$ emissions because of prolonged flooding resulting in an anaerobic soil condition. It accounts for $10-20 \%\left(50-100 \mathrm{Tg}_{\text {year }}{ }^{-1}\right)$ of total global annual $\mathrm{CH}_{4}$ emissions (Houghton et al., 1996; Reiner and Milkha, 2000). Studies comparing $\mathrm{CH}_{4}$ emissions from different tillage and crop establishment methods (CEM) under similar water management (continuous flooding/mid-season drainage/intermittent irrigation) in rice revealed that $\mathrm{CH}_{4}$ emissions were lower in DSR than with CT-TPR (Setyanto et al., 2000 and Gupta et al., 2002). Methane gas emission and global warming potential was maximum under conventional-TPR and emission of $\mathrm{N}_{2} \mathrm{O}$ was maximum under DSR crop with conservation practice of brown manuring as the addition of organic matter to soil increased the decomposition rate, which resulted in higher emission of GHGs (Bhatia et al., 2011). The reported reduction in $\mathrm{CH}_{4}$ emissions was higher in Dry-DSR than in Wet-DSR. Under continuous flooding, 
the reduction in $\mathrm{CH}_{4}$ emissions ranged from $24 \%$ to $79 \%$ in Dry-DSR and from $8 \%$ to $22 \%$ in Wet-DSR, whereas, under intermittent irrigation, the reduction ranged from $43 \%$ to $75 \%$ in Dry-DSR compared with CT-TPR. However, when DSR was combined with mid-season drainage or intermittent irrigation, the reduction in $\mathrm{CH}_{4}$ emissions increased further compared with flooded CT-TPR. For example, in Wet-DSR, the reduction in $\mathrm{CH}_{4}$ increased from 16\%-22\% (under continuous flooding) to $82 \%-92 \%$ (under mid-season drainage or intermittent irrigation) compared with CT-TPR under continuous flooding (Corton et al., 2000 and Wassmann et al., 2004) also suggested that $\mathrm{CH}_{4}$ mitigation effects can be further enhanced if Wet- or Dry-DSR is combined with mid-season drainage. This difference could be because of individual or combined effects of different soil characteristics, climatic conditions, and management such as soil $\mathrm{pH}$, redox potential, soil texture, soil salinity, temperature, rainfall, and water management (Aulakh et al., 2001). The reason for low $\mathrm{CH}_{4}$ emissions from DryDSR is aerobic conditions, especially during the early growth stage. Even under Wet-DSR, field is kept aerobic until seedlings are established. Anaerobic conditions are a prerequisite for the activities of methanogenic bacteria and $\mathrm{CH}_{4}$ production. Methane emission starts at redox potential of soil below $150 \mathrm{mV}$ and is stimulated at less than $200 \mathrm{mV} \quad$ (Jugsujinda et al., 1996; Masscheleyn et al., 1993 and Wang et al., 1993). Although water-saving technologies including Dry-DSR can reduce $\mathrm{CH}_{4}$ emissions, relatively more soil aerobic states can also increase $\mathrm{N}_{2} \mathrm{O}$ emissions. Nitrous oxide production increases at redox potentials above $250 \mathrm{mV}$ (Hou et al., 2000). In a study conducted in India comparing $\mathrm{N}_{2} \mathrm{O}$ emissions from CT-TPR and different Dry-DSR methods (CT-dry-DSR, Bed-dry-DSR, ZTdry-DSR), it was found that $\mathrm{N}_{2} \mathrm{O}$ emissions were $0.31-0.39 \mathrm{~kg} \mathrm{~N}^{-1}$ in CT-TPR, which increased to $0.90-1.1 \mathrm{~kg} \mathrm{~N}^{-1}$ in CT-dryDSR and Bed-dry-DSR and 1.3-2.2 $\mathrm{kg} \mathrm{N}^{-1}$ in ZT-dry-DSR. Similarly, a study conducted by Ishibashi et al., (2007) in western Japan also observed higher emissions of $\mathrm{N}_{2} \mathrm{O}$ under ZT-dry-DSR than in CT-TPR. These results suggest the need to deploy strategies to reduce $\mathrm{N}_{2} \mathrm{O}$ emissions from Dry-DSR for minimizing adverse impacts on the environment. Hou et al., (2000) suggested developing water management practices in such a way that soil redox potential can be kept at intermediate range (100 to $\mathrm{p} 200 \mathrm{mV})$ to minimize emissions of both $\mathrm{CH}_{4}$ and $\mathrm{N}_{2} \mathrm{O}$. This range is high enough to prevent $\mathrm{CH}_{4}$ production and low enough to encourage $\mathrm{N}_{2} \mathrm{O}$ reduction to $\mathrm{N}_{2}$ as the critical soil redox potential identified for $\mathrm{N}_{2} \mathrm{O}$ production is $\mathrm{p} 250 \mathrm{mV}$ (Hou et al., 2000). An overall effect of direct-seeding methods on GWP depends on total emissions of all three major GHGs. It has been observed that measures to reduce one source of GHG emissions often lead to increases in other GHG emissions, and this trade-off between $\mathrm{CH}_{4}$ and $\mathrm{N}_{2} \mathrm{O}$ is a major hurdle in devising an effective GHG mitigation strategy for rice (Wassmann et al., 2004). Very few studies have compared different rice production systems in terms of total GWP taking into account all three GHGs. Ishibashi et al., (2009) compared ZT-dry-DSR with CT-TPR and found ZT-dry-DSR $20 \%$ more efficient in reducing GWP. Pathak et al., (2009) simulated for Indian conditions and found that Dry-DSR on raised beds or ZT has potential to reduce $\mathrm{CO}_{2}$ equivalent $\mathrm{ha}^{-1}$ by $40-44 \%$ compared with CTTPR. Harada et al., (2007) reported that, just by changing puddling to zero tillage, GWP declined by $42 \%$ in Japan. In summary, despite relatively higher emissions of $\mathrm{N}_{2} \mathrm{O}$ in Dry-DSR, GWP of DryDSR tends to be lower than for flooded CTTPR because of substantially higher emissions of $\mathrm{CH}_{4}$ in CT-TPR. However, more systematic studies involving simultaneous measurements of three GHGs are needed to 
come to sound conclusions. Further, considering the burgeoning global demand for food, fiber, and fuel, appropriate GHG emission strategies must involve ecologically intensive crop management practices that enhance nutrient use efficiency and maintain high yields (Cassman, 1999). Globally, anthropogenic sources of methane $\left(\mathrm{CH}_{4}\right)$ and nitrous oxide $\left(\mathrm{N}_{2} \mathrm{O}\right)$ are dominated by agriculture, and agricultural $\mathrm{CH}_{4}$ and $\mathrm{N}_{2} \mathrm{O}$ emissions have increased by approximately 17 per cent from 1990 through 2005 (Forster et al., 2007). Traditional flooded paddy fields have been identified as a major source of increasing atmospheric $\mathrm{CH}_{4}$ accounting for approximately $5-19 \%$ of the annual global $\mathrm{CH}_{4}$ emissions to the atmosphere (IPCC, 2007). Although most $\mathrm{N}_{2} \mathrm{O}$ emissions are produced in uplands, several studies on $\mathrm{N}_{2} \mathrm{O}$ emissions from rice fields revealed that substantial $\mathrm{N}_{2} \mathrm{O}$ emission results from the mid-season drainage and dry-wet episodes in rice fields (Yao et al., 2010). Methane is produced by anaerobic (without oxygen) decomposition of organic matter in the soil under flooded rice cultivation. Flooding creates anaerobic conditions a few millimeters beneath the soil surface and leads to the production of methane. The absence of standing water drastically reduces emissions of methane to the atmosphere. Adopting aerobic rice will help to minimize both methane and nitrous oxide emission rates from rice fields without affecting the productivity (Shashidhar, 2008). Methane flux was almost 10 times more pronounced under continuously flooded conditions than under continuously non-flooded conditions. The significantly lower efflux of methane under aerobic (3.03 mg m-2 $\mathrm{hr}^{-1}$ ) compared to flooded rice $\left(6.16 \mathrm{mg} \mathrm{m}-2 \mathrm{hr}^{-1}\right)$ was reported by Jinsy (2014). Vial (2007) reported that approximate $50 \%$ reduction in $\mathrm{CH}_{4}$ emission under aerobic rice. So, we can say that the aerobic rice system is eco-friendly approach and safe for the environment. Simulated $\mathrm{CH}_{4}$ emission in rice ranged from 25 to $59 \mathrm{~kg} \mathrm{ha}^{-1}$, and the farmers practice had the largest emission followed by unpuddled transplanting. Emission of $\mathrm{N}_{2} \mathrm{O}$ from soil in rice as well as in wheat varied between 0.10 and $0.12 \mathrm{~kg} \mathrm{~N}_{2} \mathrm{O}-\mathrm{N} \mathrm{ha}{ }^{-1}$. Fertilizer contributed 0.24 and $0.37 \mathrm{~kg} \mathrm{~N}_{2} \mathrm{O}-\mathrm{N}$ ha $^{-1}$ in rice while it was between 0.42 and $0.54 \mathrm{~kg} \mathrm{~N}_{2} \mathrm{O}-\mathrm{N} \mathrm{ha}^{-1}$ in wheat. Farm machinery including pump used for irrigation emitted 389 to $507 \mathrm{~kg} \mathrm{CO}_{2}-\mathrm{C}$ ha ${ }^{1}$ in rice and 58 to $81 \mathrm{~kg} \mathrm{CO} 2-\mathrm{C} \mathrm{ha}^{-1}$ in wheat. Off-farm practices such as production of fertilizer contributed 117 to $199 \mathrm{~kg} \mathrm{CO}_{2}-\mathrm{C}$ ha ${ }^{1}$ in rice and 222 to $252 \mathrm{~kg} \mathrm{CO}_{2}-\mathrm{C} \mathrm{ha}^{-1}$ in wheat. Production of biocides contributed 47 to $82 \mathrm{CO}_{2}-\mathrm{C}^{-1}$ in rice, while its contribution was negligible in wheat. Application of fertilizer and biocide contributed about $40 \mathrm{~kg}$ $\mathrm{CO}_{2}-\mathrm{C} \mathrm{ha}^{-1}$ in rice-wheat system. Contribution of soil to $\mathrm{CO}_{2}$ emission was taken as zero as organic $\mathrm{C}$ remained more or less static for the last 4-5 years in this present study. Several other long-term fertility experiments in rice-wheat cropping systems in northwest India also showed static organic C (Ladha et al., 2003). Different RCTs in rice-wheat system had pronounced effects on the GWP, which varied between $2799 \mathrm{~kg} \mathrm{CO}_{2}$ equivalent $\mathrm{ha}^{-1}$ in raised-bed system and 3286 $\mathrm{CO}_{2}$ equivalent $\mathrm{ha}^{-1}$ in farmers practice. Compared to the farmers practice all the technologies reduced the GWP by 3 to $28 \%$. Previous studies using the InfoRCT model have also reported similar results (Pathak et al., 2011 and Saharawat et al., 2011) under different tillage and crop establishment practices in the RW system. Rice production contributes to global climate change through emissions of methane and nitrous oxide and in turn suffers from the consequences. Methane is formed in soil through the metabolic activities of a small but highly specific bacterial group called methanogens. Their activity increases in submerged, anaerobic condition developed in wetland rice fields, which limit the transport of oxygen into the 
soil, and the microbial activities render the water-saturated soil practically devoid of oxygen. The upland, aerobic soil does not produce methane. Water management, therefore, plays a major role in methane emission. Altering water management practices, particularly mid-season aeration by short-term drainage as well as alternate wetting and drying can greatly reduce methane emission in rice cultivation. Improving organic matter management by promoting aerobic degradation through composting or incorporating into soil during off-season drain period is another promising technique. Indian rice fields covering an area of 43.86 $\mathrm{M}$ ha emitted $3.37 \mathrm{M}$ t of $\mathrm{CH}_{4}$ in 2007 (Pathak et al., 2010). The $\mathrm{CH}_{4}$ emission estimates, the emission factors used and area covered under each rice ecosystems. The highest emission was from irrigated continuously flooded rice (34\%) followed by rainfed flood prone rice $(21 \%)$. Rainfed drought prone, single aeration, deep water and irrigated multiple aeration rice ecosystems contributed 17, 16, 8 and $4 \%$ of $\mathrm{CH}_{4}$, respectively. Rice soil is also a source of nitrous oxide, a greenhouse gas 298 times more effective than $\mathrm{CO}_{2}$. Soil contributes about $65 \%$ of the total nitrous oxide emission. The major sources are soil cultivation, fertilizer and manure application, and burning organic material and fossil fuels. Appropriate crop-management practices, which lead to increased N-use efficiency, hold the key to reduce nitrous oxide emission. Site-specific nutrient management, fertilizer placement and proper type of fertilizer supply nutrients in a better accordance with plant demands, thereby reducing nitrous oxide emission.

\section{Economics}

Several studies to evaluate the performance of DSR compared to the conventional pudddled transplanted rice. Results clearly elucidated comparable grain yield of DSR under seed- cum-fertilizer drill/ zero till/reduced till system with less water use, more water productivity and greater net profit over that of conventional puddled transplanting. The DSR established its superiority over manual transplanting in terms of higher rice-wheat system productivity with greater system net return, increased water use efficiency and substantial improvement in fertilizer use efficiency compared to manual transplanting (Singh and Ladha, 2011). Studies revealed that system productivity of aerobic ricewheat, aerobic rice-chickpea and aerobic ricemustard were higher than transplanted rice based systems (Gangwar and Pandey, 2007). The DSR also had higher number of panicles per unit area, longer panicle length, more number of grains panicle ${ }^{-1}$ and higher 1000 grain weight. A major reason for farmers' interest in DSR is the rising cost of cultivation and decreasing profits with conventional practice (CT-TPR). Growers likely prefer a technology that gives higher profit despite similar or slightly lower yield. Overall analysis of several published studies shows that various methods of direct seeding reduced the cost of production by US\$9-125 $\mathrm{ha}^{-1}$ compared with conventional practice. The largest reductions in cost occurred in practices in which reduced or zero tillage was combined with Dry-DSR. These cost reductions were largely due to either reduced labour cost or tillage cost or both under DSR systems. The effect of planting systems on grain yield, straw yield, cost of cultivation, net income and net returns per rupee invested in rice grown on sandy clay loam soil (Sanjay et al., 2006). They observed direct seeding using drum seeder produced significantly higher net income Rs.34,953 ha $\mathrm{a}^{-1}$ and returns per rupee investment (Rs. 3.12) compared to net income Rs.30,420 ha $^{-1}$ and returns per rupee investment (Rs.2.66) recorded in transplanted rice. Field experiment was conducted to compare and assess the practical feasibility of different stand- 
establishment techniques in low land irrigated rice (Budhar and Tamilselvan, 2002). Four stand-establishment techniques, viz. transplanting, throwing of seedlings, direct seeding by manual broadcasting and wet seeding by drum seeder were compared. Both the direct seeding practices registered the maximum net income of Rs. 19,039 and Rs.18,587 $\mathrm{ha}^{-1}$ with B: C ratio of 2.33 and 2.29 in manual broadcasting and drum seeder, respectively. However, these reduced costs did not always translate into increased profitability. For example, the cost of growing rice on raised beds in India was the lowest among different alternative tillage and $\mathrm{CE}$ methods but there was a net loss of returns of US\$166 ha ${ }^{-1}$ compared with CT-TPR, which was primarily due to associated lower grain yield. Increases in net returns in other directseeding methods compared to CT-TPR were highly variable, ranging from US\$1 to $132 \mathrm{ha}$ ${ }^{1}$ primarily because of large yield variability. On average, the increases in net returns with direct-seeding on puddled or zero-till soil were similar (US\$51 ha ${ }^{-1}$ ). Overall, all types of direct-seeding methods, except Bed-dryDSR, were either more profitable than or equally profitable as puddled transplanted rice. The labour and water costs are likely to increase in future which will make DSR economically more attractive to the farming community.

In conclusion, the conservation agriculture based efficient and environmental friendly alternative management methods to increase water productivity in rice cultivation. Water is undoubtedly one of the most precious natural resource; however water is becoming increasingly scarce globally. Rice production and food security largely depend on the irrigated lowland rice system, but whose sustainability is threatened by fresh water scarcity, water pollution and competition for water use. From the review, it is unambiguous that, aerobic rice is a potentially viable alternative to lowland rice when water scarcity is a limiting factor. Above all, adopting aerobic rice will help to minimize greenhouse gas emission rates from rice fields without affecting the productivity. Direct seeded rice (DSR) alternative establishment method of aerobic rice to sustain productivity of rice as well as natural resources. Aerobic rice is a projected sustainable rice production technology, which can reduce water use in rice production and produce more rice with less water. It offers certain advantages viz., less labour, less water requirement, less drudgery, early crop maturity, low production cost, proper placement of seed and fertilizer, increase fertilizer use efficiency, improve soil health for crops and less greevhouse gas (GHGs) emissions, under aerobic rice production system. However, the hurdles in achieving potential yield under aerobic system has to be overcome by focused research, then only we can make aerobic rice a potentially viable alternative to direct seeded rice (DSR). Direct seeded rice can be obtained by adopting various package and practices with scientific intervention contribute to increase the productivity and profitability of rice in Chhattisgarh state.

\section{References}

Alam, M. M., Ladha, J. K., Khan, R. S., Foyjunnessa, Rashid H., Khan, A. H., and Buresh, R. J. (2005). Leaf color chart for managing nitrogen fertilizer in lowland rice in Bangladesh. Agron. J. 97, 949959.

Ando, H., Kakuda, K., Nakayama, M., and Yokoto, K. (2000). Yield of no-tillage directseeded lowland rice as influenced by different sources and application methods of fertilizer nitrogen. Soil Sci. Plant Nutr. 46, 105-115.

Anonymous (2008). Package and Practices of Kharif Crops. CCS Haryana Agricultural University, Hisar, Haryana.

Anonymous (2016). Agricultural statistics at a glance. DAC Government of India. p. 88-89.

Anonymous. (2010). Micronutrient deficiencies in Indian soils and field usable practices for

APAARI (2000). Vision 2025: Agricultural Research for Development. Bangkok: Asia Pacific 
Association of Agricultural Research Institutions.

Aulakh, M. S., Wassmann, R., and Rennenberg, H. (2001). Methane emissions from rice fields: Quantification, mechanisms, role of management, and mitigation options. Advan. Agron. 70, 93260.

Balasubramanian, V. and Hill, J.E. (2002).) Directseeding of rice in Asia: emerging issues and strategic research needs for the 21 st century. In: Pandey et al., (eds.): Direct-seeding: research strategies and opportunities. IRRI Los Banos, Phillipines, pp. 15-39.

Baltazar, A. M., and De Datta, S. K. (1992). Weed management in rice. Weed Abstr.41,495-508.

Barclay, A. (2006). The direct approach: A return to the ways of their forefathers has seen Indian and Bangladeshi rice farmers reduce their cost for water and address the growing problem of labour shortages. Rice Today. 5(2): 12-18.

Barker, R; Dawe, D; Tuong, T.P; Bhuiyan, S.I. and Guerra, L.C.(1998). The outlook for water resources in the year 2020: Challenges for research on water management in rice production. In: Assessment and Orientation Towards the 21st Century, Proceedings of 19th Session of the International Rice Commission, 7-9 September 1998, Cairo, Egypt. Food and Agricultural Organization, Rome, 1998, 96-109.

Belder, P; Bouman. BAM; Spiertz, JHJ; Peng, S; Castan, AR and Visperas, RM (2005). Crop performance, nitrogen and water use in flooded and aerobic rice. Plant and Soil. 2005; 273(1, 2):167-182.

Bhatia, A., Ghosh, A., Kumar, V., Tomer, R., Singh, S.D and Pathak, H.,(2011). Effect of elevated tropospheric ozone on methane and nitrous oxide emission from rice soil in north India. Agric Ecosys Environ. 144:21-28.

Bhushan, Lav., Ladha, J.K., Gupta, R.K., Singh, S., Tirole-Padre, A., Saharawat, Y.S., Gathala, M. and Pathak, H. (2007). Saving of water and labor in rice-wheat system with no-tillage and direct seeding technologies. Agron. J., 99: 1288-1296.

Bonman, J.M. (1992). Durable resistance to rice blast disease-environmental influences. Euphytica.63:115-23.

Bonman, J.M. and Leung, H., (2004). Breeding for durable resistance to rice blast disease dream or reality? Phytopathology 93, S113 Publication No. P-2003-0110-SSA. American Phytopathological Society Annual Meeting.

Bouman, B.A.M. (2002). Crop-water relations in ricewheat cropping systems and water management practices in a marginally sodic, medium-textured soil. In: BAM. Bouman et al., (ed..) Water-wise rice production. International Rice Research
Institute, Los Banos, Philippines, pp. 223-235.

Bouman, B.A.M., Lampayan, R.M. and Tuong, T.P. (2007). Water Management in Irrigated Rice: Coping with Water Scarcity. International Rice Research Institute, Los Banos, Philippines, 54p. ,

Bouman, B.A.M., Peng, S., Castaneda, A.R. and Visperas, R.M.(2005). Yield and water use of irrigated tropical aerobic rice systems. Agricultural Water Management. 74:87-105.

Bouman, B.A.M., Wang, H., Yang, X., Zhao, J. and Wang, C. (2002). Aerobic rice (Han Dao); A new way of growing rice in wate-short areas. In: Proceedings of the 12th International Soil Conservation Organisation Conference, 26-31 May, 2002. Beijing, China. Tsinghua University Press, 2002, 175-181.

Budhar, M.N. and Tamilselvan, N. (2002). Effect of stand-establishment techniques on yield and economics of lowland irrigated rice (Oryza sativa). Indian Journal of Agronomy. 51:123-27.

Cassman, K. G. (1999). Ecological intensification of cereal production systems: Yield potential, soil quality, and precision agriculture. Proc. Natl. Acad. Sci. USA 96, 5952-59.

Castaneda, A.R., Bouman, B.A.M., Peng, S. and Visperas, R.M.(2002).The potential of aerobic rice to reduce water use in water-scarce irrigated lowlands in the tropics: opportunities and challenges. In: Bouman B A M, Hengsdijk H, Hardy B, Bindraban PS, Tuong TP and Ladha JK (eds) Water-wise rice production. Proc International Workshop on Water-wise Rice Production, 8-11 April 2002, Los Baños, Philippines. International Rice Research Institute, Los Baños, Philippines, 2002, 165-76.

Chan, C.C., and Nor, M.A.M. (1993). Impacts and implications of direct seeding on irrigation requirement and systems management. In : Paper presented at the workshop on water and direct seeding for rice, 14-16 June, 1993, Muda Agricultural development Authority, Ampang Jajar, Alor Setar, Malaysia.

Chaudhary, V.P., Pandey, D.K. and Sharma, S.K. (2008). Energy requirement of different weed management practices for aerobic rice in India. Agricultural Mechanization in Asia, Africa and Latin America. 39(2):39-46.

Choudhary, B.U., Bouman, B.A.M. and Singh, A.K.(2007). Yield and water productivity of ricewheat on raised beds at New Delhi, India. Field. Crops. Res., 100: 229-239.

Christianson, C. B., and Schultz, J. J. (1991). Strategies to improve nitrogen fertilizer use efficiency in upland systems. In "Paper Presented at Training Program: Plant Nutrient Management for Sustainable Agriculture," October 1991. IFDC, 
Muscle Shoals, Alabama.

Corton, T. M., Bajita, J., Grospe, F., Pamplona, R., Wassmann, R., and Lantin, R. S.(2000). Methane emission from irrigated and intensively managed rice fields in Central Luzon (Philippines). Nutrient Cycle Agroecosystem Nutr. Cycl. Agroecosyst. 58, 37-53.

Datta, S. P., Saharan,N., and Rattan, R. K. (2003). Micronutrient fertilizers, sources and methods of application. In "Integrated Micronutrient Management for Sustainable Agriculture"(D. K. Das and D. Saha, Eds.), pp. 71-89.

Dingkuhn, M.., Schnier, H. F., De Datta, S. K., Dorffling, K., and Javellana, C. (1991). Relationships between ripening-phase productivity and crop duration, canopy photosynthesis and senescence in transplanted and direct-seeded lowland rice. Field Crops Res. 26, 327-345.

Direct seeding: research strategies and opportunities. Los Banos (Philippines): International Rice Research Institute, pp. 3-14.

Dogar, M.A. and Hai, T. (1980). Effect of N, P and $\mathrm{HCO}_{3}^{-}$levels in the nutrient solution on rate of $\mathrm{Zn}$ absorption by rice roots and $\mathrm{Zn}$ content. $\mathrm{Z}$. Pflanzen physiologie. 98: 203-12.

Duxbury, J.M., Abrol, I.P., Gupta, R.K., and K.F. Bronson, K.F.(2000). Analysis of long-term fertility experiments with rice-wheat rotations in South Asia. In I.P. Abrol, K.F. Bronson, J.M. Duxbury, and R.K. Gupta (eds.), Long-term soil fertility experiments in rice-wheat cropping systems. Rice-Wheat Consortium Paper Series 6. New Delhi, India: RWC. Pp. vii-xxii.

effects in rice culture. "Rice Is Life: Scientific Perspectives for the 21st Century. Proceedings of the World Rice Research Conference, 4-7 November 2004, Tsukuba, Japan”, pp. 372-373. Saleque, M.A. and Kirk, G.J.D. (1995). Root induced solubilization of phosphate in the rhizosphere of low land rice. New Phytology. 129: 325-36.

FAO-Food and Agriculture Organization (1999). In "Report of Global Workshop on Red Rice Control, August 30 to September 3, 1999, Varadero, Cuba". FAO, Rome p. 155.

Farooq, M., Basra, S.M.A., Afzal, I. and Khaliq, A. (2006). Optimization of hydro-priming techniques for rice seed invigoration. Seed Sci. Technol. 34: 507-512.

Fashola, O.O., Hayashi, K. and Wakatsuki, T. (2002). Effect of water management and polyolefin-coated urea on growth and nitrogen uptake of indica rice. J. Plant Nutr. 25: 2173-90.

Forno, D.A., Yoshida, S. and Acher, C.J.(1975). Zinc deficiency in rice. I. soil factors associated with the deficiency. Plant and soil. 42: 537-50.
Forster, P., Ramaswamy, V., Artaxo, P., Berntsen, T., Betts, R. and Fahey, D.W. (2007). Changes in atmospheric constituents and in radiative forcing. In: Solomon S, Qin D, Manning M, Chen Z, Marquis M, Averyt K B, Tignor M and Miller H L (eds.), Climate Change 2007: The Physical Science Basis. Cambridge University press, Cambridge, U.K, 176.

Gaire, R., Dahal, K.R. and Amgain, L.P. (2013). Effect of different mulching materials on weed dynamics and yield of direct seeded rice in Chitwan, Nepal, Agronomy Journal of Nepal, 03: 73.

Gangwar K.S. and Pandey D.K, (2007). Aerobic ricebased cropping systems for higher productivity and profitability. Indian Farming, November, 2007, pp. 3-6.

Gao, X.P., Zou, C.Q., Fan, X.Y., Zhang, F.S. and Hoffland, E. (2006). From flooded to aerobic conditions in rice cultivation: consequences for zinc uptake. Plant Soil. 280: 41-47.

Gathala, M. K., Ladha, J. K., Kumar, V., Saharawat, Y. S., Kumar V., Sharma, P. K., Sharma, S., and Pathak, H. (2011). Tillage and crop establishment affects sustainability of South Asian rice-wheat system. Agron. J. (In press).

Geethalakshmi, V., Ramesh, T., Muthisolai, A. and Lakshmanan, A. (2009). Agronomic evaluation of rice cultivation system for water and grain productivity.

www.scribd.com/doc/4991320/agronomicevolutio $n$.

George, Daly. (2018). Aerobic rice: Rice for future. International Journal of Chemical Studies. 6 (6): 481-85.

Gill, M.S., Kumar, P. and Kumar, A. ( 2006). Growth and yield of direct seeded rice (Oryza sativa) as influenced by seeding technique and seed rate under irrigated conditions. Indian Journal of Agronomy. 51(4):283-87.

Giordano, P.M. and Mortvedt, J.J. (1972). Rice response to $\mathrm{Zn}$ in flooded and non-flooded soil. Agronomy Journal. 64: 521-24.

Golden, B. R., Slaton, N. A., Norman, R. J., Wilson, C. E. Jr., and DeLong, R. E. (2009). Evaluation of polymer-coated urea for direct-seeded, delayedflood rice production. Soil Sci. Soc. Am. J. 73, 375-383.

Gopal, R., Jat, R.K., Malik, R.K., Kumar, V., Alam, M.M., Jat, M.L., Mazid, M.A., Saharawat, Y.S., McDonald, A. and Gupta, R. (2010). Direct DrySeeded Rice Production Technology and Weed Management in Rice Based Systems. Technical Bulletin. International Maize and Wheat Improvement Center, New Delhi, India, 28pp.

Gupta, R. and Sayre, K. (2007). Conservation agriculture in South Asia. Journal of Agricultural 
Science. 145: 207-14.

Gupta, R. K., Naresh, R. K., Hobbs, P. R., and Ladha, J. K. (2002). Adopting conservation agriculture in rice-wheat systems of the Indo-Gangetic PlainsNew opportunities for saving on water. In "Proceedings of the International Workshop on Water-Wise Rice Production" (B. A. M. Bouman, H. Hengsdijk, B. Hardy, B. Bindraban, T. P. Toung, and J. K. Ladha, Eds.), pp. 207-222. International Rice Research Institute, Los Bañ os, Philippines.

Gupta, R.K. and Seth, A. (2007). A review of resource conserving technologies for sustainable management of the rice-wheat cropping systems of the Indo-Gangetic plains. Crop Prot., 26 : 436447.

Gupta, R.K., Ladha, J.K., Singh, S., Singh, R., Jat, M.L., Saharawat, Y., Singh, V.P., Singh, S.S., Singh, G., Sah, G., Gathala, M. and Sharma, R.K. (2006). Production Technology for Direct Seeded Rice. Technical Bulletin Series 8. In "Rice-Wheat Consortium for the Indo-Gangetic Plains, New Delhi, India," 14pp.

Gupta, R.K., Naresh, R.K., Hobbs, P.R., Jiaguo,Z. and Ladha. J.K. (2003). Sustainability of post-green revolution agriculture: The rice-wheat cropping systems of the Indo-Gangetic Plains and China. In J.K. Ladha, J.E. Hill, J.M. Duxbury, R.K Gupta, and R.J. Buresh (eds.), Improving the productivity and sustainability of rice-wheat systems: Issues and impacts. ASA Special Publication Number 65. Madison, Wisconsin, USA: ASA-CSSA-SSSA. pp. 1-26.

Harada, H., Hitomi, K., and Hayato, S. (2007). Reduction in greenhouse gas emissions by notilling rice cultivation in Hachirogata polder, northern Japan: Life-cycle inventory analysis. Soil Sci. Plant Nutr. 53, 668-677.

Hou, A. X., Chen, G. X., Wang, Z. P., Van Cleemput, O., and Patrick, W. H. Jr. (2000). Methane and nitrous oxide emissions form a rice field in relation to soil redox and microbiological processes. Soil Sci. Soc. Am. J. 64: 2180-86.

Houghton, J. T., Meira Filho, L. G., Callander, B. A., Harris, N., Katterberg, A., and Maskell, K. (1996). IPCC report on climate change: The science of climate change. "WG1 Contribution to the IPCC Second Assessment Report on Methane Emission from Rice Cultivation", Cambridge University Press, Cambridge, UK.

Humphreys, E., Kukal, S.S., Christen, E.W., Hira, G.S., Sharma, R.K., 2010. Halting the groundwater decline in north-west India-Which crop technologies will be winners? Adv. Agron. 109: 155-217.

Information Age. Philadelphia, PA: International
Congress of Soil Science. Abstract available online at http:// crops.confex.com/crops/wc2006/techprogram/P14 848. htm (verified 10/1/07).

IPCC [Intergovernmental Panel on Climate Change] Climate Change. (2007). The Physical science Basis. Cambridge University Press, Cambridge, U.K, 176.

IRRI (2010).Site-specific nutrient management,www.irri.org/irrc/ssnm. Accessed 30April,2010.

Ishibashi, E., Yamamoto, S., Akai, N., and Tsuruta, H. (2007). The influence of no-tilled direct seeding cultivation on greenhouse gas emissions from rice paddy fields in Okayama, Western Japan. 4. Major factors controlling nitrous oxide emission from rice paddy fields under no-till direct seeding cultivation. Jpn. J. Soil Sci. Plant Nutr. 78: 45363.

Ishibashi, E., Yamamoto, S., Akai, N., and Tsuruta, H. (2009). The influence of no-tilled direct seeding cultivation on greenhouse gas emissions from rice paddy fields in Okayama, Western Japan. 5. Annual emission of $\mathrm{CH}_{4}, \mathrm{~N}_{2} \mathrm{O}$ and $\mathrm{CO}_{2}$ from rice paddy fields under different cultivation methods and carbon sequestration into paddy soils. Jpn. J. Soil Sci. Plant Nutr. 80: 123-135

Jat, M. L., Chandna, P., Gupta, R, K., Sharma, S.K. and Gill, M. A. (2006). Laser Land Leveling: A Precursor Technology for Resource Conservation. Rice-Wheat Consortium Technical Bulletin Series 7. New Delhi, India: Rice-Wheat Consortium for the Indo-Gangetic Plains.

Jat, M.L., Gathala, M.K., Ladha, J.K., Saharawat, Y.S., Jat, A.S. and Kumar, V. (2009). Evaluation of precision land leveling and double zero-till systems in the rice-wheat rotation: Water use, productivity, profitability and soil physical properties. Soil and Tillage Research. 105: 112121.

Jat, M.L., Gupt, R., Saharawat, Y.S. and Khosla, R. (2011). Layering precision land leveling and furrow irrigated Raised Bed Planting: Productivity and Input Use Efficiency of Irrigated Bread Wheat in Indo-Gangetic Plains. Am. J. Plant. Sci., 2(3): $1-11$.

Jinsy, V.S. (2014). Productivity analysis of aerobic rice (Oryza sativa L.) and its impact on green house gas emission. Ph. D thesis, Kerala Agricultural University, Thrissur, 223.

Jinsy, V.S., Pillai, P.S. and Jacob, J. (2015). Productivity analysis of aerobic rice in the lowlands of Southern Kerala. Journal of Tropical Agriculture. 53(1):1-7.

Johnson, D. E., and Mortimer, A. M. (2005). Issues for integrated weed management and decision support 
in direct-seeded rice. In "Rice Is Life: Scientific Perspectives for the $21^{\text {st }}$ Century" (K. Toriyama, K. L. Heong, and B. Hardy, Eds.), pp. 211-214. International Rice Research Institute, Los Bañ os, Philippines and Japan International Research Center for Agricultural Sciences, Tsukuba, Japan.

Joshi, E., Kumar, D., Lal, B.V., Gautam, P. and Vyas, A.K. (2013). Management of direct seeded rice for enhanced resource - use efficiency. Plant Knowledge Journal 2(3): 119-34.

Jugsujinda, A., Delaune, R. D., and Lindau, C. W. (1996). Factors controlling carbon dioxide and methane production in acid sulfate soils. Water Air Soil Pollut. 87: 345-55.

Kadiyala, M.D.M., Mylavarapu, R.S., Reddy, G.B. and Reddy, M.D. (2012. .Impact of Aerobic Rice Cultivation on Growth, Yield, and Water Productivity of Rice-Maize Rotation in Semiarid Tropics. Climatology \& Water Management. 104(6):1751-65.

Karim, R. S. M., Man, A. B. and Sahid, I. B. (2004). Weed problems and their management in rice fields of Malaysia: An overview. Weed Biol. Manage. 4: 177-86.

Kato, Y., Kamoshita, A. and Yamagishi, J. (2006). Growth of rice (Oryza sativa L.) under upland conditions with different levels of water supply.Plant Production Science. 9: 435-45.

Kaur, Jagmohan and Singh, Avtar (2017). Direct seeded rice: Prospects, problems/constraints and researchable issues in India. Current Agriculture Research Journal. 5(1): 13-32.

Kaya, M.D., Okcub, G., Ataka, M.C., Ikilic, Y. and Kolsarica, O. (2006). Seed treatments to overcome salt and drought stress during germination in sunflower (Helianthus annuus L.). Eur J Agron. 24: 291-95.

Khade, V.N., Patil, B.D., Khanvilkar, S.A. and Chavan, L.S. (1993). Effect of seeding rates and level of $\mathrm{N}$ on yield of direct-seeded (Rahu) summer rice in Konkan. J Maharash Agric Univ. 18: $32-35$.

Kim, C.K. (1987). Disease dispersal gradients of rice blast from point source. Korean. Journal of Plant Protection. 3: 131-36.

Kirk, G.J.D. and Bajita, L.B. (1995). Root introduced iron oxidation, $\mathrm{pH}$ changes and zinc solublization in the rhizosphere of lowland rice. New Phytopaphology. 131: 129-37.

Kreye, C., Bouman, B.A.M., Castaneda, A.R., Lampayan, R.M., Faronilo, J.E., Lactaoen, A.T. and Fernadez, L. (2009). Possible causes of yield failure in tropical aerobic rice. Field Crops Research. 111: 197-206.

Kumar, P., Jha, D., Kumar, A., Chaudhary, M.K., Grover, R.K., Singh, R.K., Mitra, A., Joshi,
P.K., Singh, A., Badal, P.S., Mittal, S, and J. Ali, J. (2002). Economic analysis of total factor productivity of crop sector in Indo-Gangetic Plain of India by district and region. Agricultural Economics Research Report 2. New Delhi, India: Indian Agricultural Research Institute.

Kumar, V. and Ladha, J.K. (2011). Direct-seeding of rice : recent developments and future research needs. Adv. Agron., 111: 297-413.

Kumar, V., Bellinder, R.R., Gupta, R.K., Malik, R.K. and Brainard, D.C. (2008). Role of herbicide resistant rice in promoting resource conservation technologies in rice-wheat cropping systems in India: A review. Crop Prot., 27: 290-301.

Ladha, J. K., Kumar, V., Alam, M. M., Sharma, S., Gathala, M., Chandna, P., Saharawat, Y. S., and Balasubramanian, V. (2009). Integrating crop and resource management technologies for enhanced productivity, profitability, and sustainability of the rice-wheat system in South Asia. In "Integrated Crop and Resource Management in the RiceWheat System of South Asia" (J. K. Ladha, Y. Singh, O. Erenstein, and B. Hardy, Eds.), pp. 69108. International Rice Research Institute, Los Ban os, Philippines.

Ladha, J.K., Hill, J.E., Duxbury, J.M., Raj, K. Gupta and Buresh, R.J. (2003). Improving the productivity and sustainability of rice-wheat systems: Issues and Impacts. ASA Special Publication No. 65, pp. 231.

Ladha, J.K., Pathak, H., Krupnik, T.J., Six, J. and Van, Kessel. C. (2005). Efficiency of fertilizer nitrogen in cereal production: retrospects and prospects. Advances in Agronomy 87: 85-156.

management affecting methane emissions from irrigated and rainfed rice in Central Java (Indonesia). Nutr. Cycl. Agroecosyst. 58, 85-93.

Mandal, B., Hazra, G.C. and Mandal, L.N. (2000). Soil management influences on zinc desorption for rice and maize nutrition. Soil Science Society American Journal. 64: 1699-1705

Marasini, S., Joshi, T.N. and Amgain, L.P. (2016). Direct seeded rice cultivation method: A new technology for climate change and food security. The Journal of Agriculture and Environment. 17: 30-38.

Masscheleyn, P. H., Delaune, R. D. and Patrick, W. H. Jr. (1993). Methane and nitrous oxide emission from laboratory measurements of rice soil suspension: Effect of soil oxidation-reduction status. Chemosphere 26, 251-260.

Mohanty, S. (2014). Rice in South Asia. Rice Today. 13: $40-41$.

Neue,H.U. and Bloom, P.R. (1987). Nutrient kinetics and availability in flooded Soil. In: Proceedings of the International Rice Research Conference, 
International Rice Research Institute, Los Bano’s Philippines.

Noldin, J. A., Chandler, J. M., Ketchersid, M. L. and McCauley, G. N. (1999). Red rice (Oryza sativa) biology. II. Ecotype sensitivity to herbicides. Weed Technol. 13, 19-24.

OECD. (2000). Environmental Indicators for Agriculture Methods and Results. Executive summary. OECD, Paris.

Ottis, B. V., Smith, K. L., Scott, R. C., and Talbert, R. E. (2005). Rice yield and quality as affected by cultivar and red rice (Oryza sativa) density. Weed Sci. 53, 499-504.

Oyediran, I.O. and Heinrichs, E.A. (2001). Arthropod populations and rice yields in direct seeded and transplanted lowland rice in West Africa. Int. J. Pest Manage. 47: 195-200.

Pal, D. K., Bhattacharya, T., Gupta, R. and Khadka, Y.G. (2005). Role of fine-grained micas in potassium management of a long-term experiment on rice-rice wheat system in soils of the IndoGangetic Plains at Bharwah, Nepal. Clay Research 24, 63-81.

Pal, S., Datta, S. P., Rattan, R. K., and Singh, A. K. (2008). Diagnosis and amelioration of iron deficiency under aerobic rice. J. Plant Nutr. 31: 919-40.

Pandey, N.C., Samantaray, R.N. and Mohanty, S.K. (1985). Nutrient Change in direct- seeded submerged rice soils with varying nutriaenvironments. Plant Soil. 88: 299-306.

Pandey, S. and Velasco, L.E. (1999). Economics of alternative rice establishment methods in Asia: a strategic analysis. In: Social Sciences Division Discussion Paper, International Rice Research Institute. Los Bano's, Philippines.

Pandey, S. and Velasec, L. (2002). Economics of direct seeding in Asia; Pattern of adoption and research priorities. In: Pandey S, Mortimer M, Eade L, Tuong TP, Lopez K and Hardi B (Eds.).

Park, S. T., Son, Y., Lee, S. K. and Chung, K. S. (1990). Studies on major cultivation methods for dry direct seeding. Res. Rep. RDA (Rice) 32, 1828.

Pasricha, N. S., Bansal, S. K., Singh, K. and Deen, M. (2006). Reduced tillage for efficient management of crop residue, irrigation water and fertilizer nitrogen in wheat grown in rotation with rice. In 18th World Congress of Soil Science. Frontiers of Soil Science: Technology and the

Patel, D.P., Das, A., Munda, G.C., Ghosh, P.K., Borodoloi, J.S. and Kumar, M.(2010). Evaluation of yield and physiological attributes of highyielding rice varieties under aerobic and floodedirrigated management practices in mid-hills eco system. Agricultural Water Management. 97(9):1269-76.

Pathak, H., Bhatia, A., Jain, N. and Aggarwal, P.K. (2010). Greenhouse Gas Emission and Mitigation in Indian Agriculture - A Review, In ING Bulletins on Regional Assessment of Reactive Nitrogen, Bulletin No. 19, (Ed. Bijay Singh), SCON-ING, New Delhi, pp. i-iv \& 1-34.

Pathak, H., Saharawat, Y. S., Gathala, M. K., Mohanty, S., and Ladha, J. K. (2009). Simulating environmental impact of resource-conserving technologies in the rice-wheat system of the IndoGangetic Plains. In "Integrated Crop and Resource Management in the Rice-Wheat System of South Asia" (J. K. Ladha, Y. Singh, O. Erenstein, and B. Hardy, Eds.), pp. 321-333. International Rice Research Institute, Los Bañ os, Philippines.

Pathak, H., Saharawat, Y.S., Gathala, M. and Ladha, J.K. (2011). Impact of resource-conservation technologies on productivity and greenhouse gas emission in rice-wheat system. Greenhouse Gases: Sci. Technol., 1: 1-17.

Pathak, H., Tewari, A.N., Sankhyan, S., Ankhyan, Dubey,D.S., U Mina, U., Virender, K. Singh., Jain, N. and Bhatia, A. (2011). Direct-seeded rice: Potential, performance and problems - A review. Current Advances in Agricultural Sciences. 3(2): 77-88.

Pepsico International (2011). Direct seeding of paddythe work of pepsico reported in indiawaterportal. http://www.indiawaterportal.org/post/6 754.

PhilRice (The Philippine Rice Research Institute). (2002). Integrated nutrient management for rice production. In "Rice Technology Bulletin No. 45" p. 24. The Philippine Rice Research Institute (PhilRice), Maligaya, Nueva Ecija, Philippines.

Pongprasert, S. (1995). Insect and disease control in wet-seeded rice in Thailand. In: Moody, K. (ed.), Constraints, Opportunities, and Innovations for Wet-seeded Rice, Discussion Paper Series No. 10. International Rice Research Institute, Los Bano ^s, Philippines, pp 118-132.

Prabhu, A.S., Filippi, M.C., Arau, jo, L.G. and Faria, J.C. (2002). Genetic and phenotypic characterization of isolates of Pyricularia grisea from the rice cultivars Epagri 108 and 109 in the state of Tocantins. Fitopatologia Brasileira. 27: 566-73.

Prasad, R. (2007). Phosphorus management in the ricewheat cropping system of the Indo- Gangetic Plain. Better Crops-India. 1: 8-11.

Prasad,R. (2011). Aerobic rice systems. Advances in Agronomy. 11: 207-47.

Prot, J.C., Soriano,I.R.S. and Matias, D.M. (1994). Major root- parasitic nematodes associated with irrigated rice in the Philippines. Fundamental 
Applied Nematology. 17: 75-78.

Rao, A.N., Johnson,D.E., Sivaprasad, B., Ladha, J.K. and Mortimer, A.M. (2007). Weed management in direct-seeded rice. Advances in Agronomy. 93: 153-255.

Reddy, M.D., Reddy, S.N. and Ramulu, V. (2010). Evaluation of rice cultivars for aerobic and transplanted conditions. Agricultural Science Digest. 30(2): 129-32.

Reiner, W. and Aulakh, M.S. (2000). The role of rice plants in regulating mechanisms of methane emissions. Biol Fertil Soils. 31: 20-29.

Sah, D.N. and Bonman, J.M. (2008). Effect of seed bed management on blast development in susceptible and partially resistant rice cultivars. Journal of Phytopathology. 136: 73-81. Saharawat, Y.S., Gathala, M., Ladha, J.K., Malik, R.K., Singh, S., Jat, M.L., Gupta, R., Pathak H. and Singh, K. (2009). Evaluation and promotion of integrated crop and resource management in Rice-Wheat system in North West India. In: Ladha JK et al., (Eds.) Integrated crop and resource management in rice-wheat system of South Asia. Los Banos, Phillipines, pp. 133-150.

Saharawat, Y.S., Ladha, J.K., Jat, M.L., Gathala, M.K. and Chaudhary, N. (2011). InfoRCT: productivity, income and environment simulation tool for conservation agriculture based rice-wheat rotation. In: Proc. of 5th World Conservation Agriculture Conference. ACIAR Publication, pp. 152-153.

Saharawat, Y.S., Ladha, J.K., Pathak, H., Gathala, M., Chaudhary, Neelam and M. L. Jat, M.L (2012). Simulation of resource-conserving technologies on productivity, income and greenhouse gas GHG emission in rice-wheat system. Journal of Soil Science and Environmental Management. 3 (1): 922.

Saharawat, Y.S., Singh, B., Malik, R.K., Ladha, J.K., Gathala, M.K., Jat, M.L. and Kumar, V. (2010). Evaluation of alternative tillage and crop establishment methods in a rice-wheat rotation in North Western IGP. Field Crop Res., 116: 260267.

Sahid, I.B. and Hossain, M.S. (1995). The effect of flooding and sowing depth on the survival and growth of five rice-weed species. Plant Protection Quaterly. 10: 139-42.

Saigusa, M. (2005). New fertilizer management to maximize yield and minimize environmental

Sanjay, M.T. and Prabhakara, T. K. and Nanjappa, H.V. (2006). Productivity, energetic and economics of different systems of crop establishment in rice (Oryza sativa L.). Crop Research. 31: 350-53.

Sarkar, R.K., Sanjukta, D., and Das, S. (2003). Yield of rainfed lowland rice with medium water depth under anaerobic direct seeding and transplanting. Tropical science. 43: 192-98.

Savary,S., Castilla, N.P., Elazegui, F.A. and Teng, P.S. (2005). Multiple effects of two drivers of agricultural change, labour shortage and water scarcity, on rice pest profiles in tropical Asia. Field Crop Research. 91: 263-71.

Sayre, K. D., Limon-Ortega, A., Govaerts, B., Martinez, A. and Cruzcano, M. (2005). Effects following twelve years of irrigated permanent raised bed planting systems in northwest Mexico. Proceedings of an International Conference, 29 June to July 2005: Soil, Agriculture, Environment, Landscape, pp. 99-106. Brno, Czech Republic: ISTRO.

Setyanto, P., Makarim, A. K., Fagi, A. M., Wassmann, R., and Buendia, L. V. (2000). Crop

Sharma, P.K., Bhushan, L., Ladha, J.K., Naresh, R.K., Gupta, R.K., Balasubramanian, V. and

Shashidhar, H.E. (2008). Aerobc rice- An efficient water management strategy for rice production. In: Aswathanarayana U. (ed.), Food and Water Security. Taylor and Francis, 2300 AK Leiden, The Netherlands, 131-139.

Shoji, S., Delgado, J., Mosier, A., and Miura, Y. (2001). Use of controlled release fertilizers and nitrification inhibitors to increase nitrogen use efficiency and to conserve air and water quality. Commun. Soil Sci. Plant Anal. 32, 1051-1070.

Shukla, A.K., Ladha, J.K., Singh, V.K., Dwivedi, B.S., Gupta, R.K, Sharma, S.K., Balasubramanian, V., Singh, Y., Pathak, H., Padre, A.T. and Yadav, R.L. (2004). Calibrating the leaf color chart for $\mathrm{N}$ management in different genotypes of rice and wheat in a system perspective. Agron. J., 96: 1606-1621.

Singh, A.K. and Chinnaswamy, V. (2006). Aerobic rice- Prospects for enhancing water productivity. Indian Farming. 56(56-58): 2-7.

Singh, B., Singh, Y., Ladha, J. K., Bronson, K. F., Balasubramanian, V., Singh, J. and Khind, C. S. (2002). Chlorophyll meter- and leaf color chartbased nitrogen management for rice and wheat in Northwestern India. Agronomy Journal 94, 821829.

Singh, N., Singh, B., Rai, A.B., Dubey, A.K. and Rai, Ashok. (2012). Impact of Direct Seeded Rice (DSR) For Resource Conservation. Indian Research Journal of Extension Education, (Special Issue). 2: 6-9.

Singh, S., Bhushan, L., Ladha, J. K., Gupta, R. K., Rao, A. N., and Sivaprasad, B. (2006). Weed management in dry-seeded rice (Oryza sativa) cultivated in the furrow-irrigated raised-bed planting system. Crop Prot. 25, 487-495.

Singh, S., Malik, R.K., Mongia, A.D., Sharma, R.K., 
Sidhu, B.S. and Singh, B., (2005). Haryana and Punjab. In "Agenda Notes. 13th Regional Technical Co-Ordination Committee Meeting, 6-8 February 2005, Dhaka, Bangladesh," pp 27-29.

Singh, S.P., Paikra, K.K. and Patel, C.R. (2018). Direct seeded rice: A resource conservation technology for increasing productivity and profitability of aerobic rice (Oryza sativa L.) in Raigarh district of Chhattisgarh plains International Journal of Agriculture Sciences. 10 (10): 6174-76.

Singh, V. and Ladha, J.K. (2011). Direct seeding of rice: Recent developments and future research needs. Advances in Agronomy 11: 297-413.

Singh,S., Ladha, J.K., Gupta, K., Bhusan, L. and Rao, A.N. (2008). Weed management in aerobic rice systems under varying establishment methods. Crop Protection. 27(3-5): 660-71.

Sritharan, N., Vijayalakshmi, C. and Selvaraj, P.K. (2010). Effect of micro-irrigation technique on physiological and yield traits in aerobic rice. International Journal of Agriculture, Environment and Biotechnology. 3(1):26-28.

Stutterheim, N. C., Barbier, J. M., and Nougaredes, B. (1994). The efficiency of fertilizer nitrogen in irrigated, direct seeded rice (O. sativa L.) in Europe. Fert. Res. 37, 235-244.

Their correction Indian Institute of Soil Science, Bhopal, (accessed June 9, 2010). www.iiss.nic.in/ Recommendations1.pdf,

Tuong, L. (2008). Studies on direct-seeding adaptability of Cambodian rice cultivars and development of cultivars with good eating quality. $\mathrm{PhD}$ thesis, Science of Plant and Animal Production, United Graduate School of Agricultural Science, Tokyo University of Agriculture and Technology, Japan.

Vial, L.K. (2007). Alternate-wet-and-Dry (AWD) Rice Systems. A report for Nuffield Australia Project No. RABO 090.

Wade, L.J., George, T., Ladha, J.K.,Singh, U., Bhuiyan, S.I. and Pandey, S. (1998). Opportunities to manipulate nutrient-by-water interactions in rainfed lowland rice systems. Field Crop Research. 56: 93-112.

Wang, H., Bouman, B.A.M., Zhao, D., Wang, C. and Moya, P.F. (2002). Aerobic rice in northern China: opportunities and challenges. In: Bouman,
B. A. M., Hengsdijk, H., Hardy, B., Bindraban ,P. S., Tuong, T. P. and Ladha, J. K. (eds), Waterwise rice production. Proc International Workshop on Water-wise Rice Production, 8-11 April 2002, Los Baños, Philippines. International Rice Research Institute, Los Baños, Philippines, 143154.

Wang, H.Q. and Tang, S.X.(2000). Upland rice production in China: its past, today and future. Paper presented at Aerobic rice workshop, 7-8 September, 2000. International Rice Research Institute, Los Banos, Philippines.

Wang, Z., Delaune, R. D., Masscheleyn, P. H., and Patrick, W. H. Jr. (1993). Soil redox and $\mathrm{pH}$ effects on methane production in a flooded rice soil. Soil Sci. Soc. Am. J. 57: 382-85.

Wassmann, R., Neue, H.U., Ladha, J.K., Aulakh, M.S. (2004). Mitigating greenhouse gas emissions from rice-wheat cropping systems in Asia. Environ Sustain Dev. 6: 65-90.

Wells, B. R., and Norman, R. J. (1992). Response of rice to amended ureas as nitrogen sources. In "Arkansas Soil Fertility Studies 1991" (W. E. Sabbe, Ed.), Res. Ser. 421, pp. 65-69. Ark. Agric. Exp. Stn, Fayetteville.

Wilson, C. E. Jr., Norman, R. J., and Wells, B. R. (1990). Dicyandiamide influence on uptake of preplant-applied fertilizer nitrogen by rice. Soil Sci. Soc. Am. J. 54, 1157-1161.

Yadvinder, S., Brar, N.K., Humphreys, E., Singh, B., Nayyar, A., Timsina, J. (2008). Yield and nitrogen use efficiency of permanent bed rice-wheat systems in northwest India: effect of $\mathrm{N}$ fertilization, mulching and crop establishment method. In: Humpherys, Roth (Eds.): Permanent beds and rice-residue management for rice-wheat system of the IGP. ACIAR Proc., 127: 62-97.

Yao Z, Zhou Z, Zheng X, Xie B, Mei B, Wang R, et $a l$., (2010). Effects of organic matter incorporation on nitrous oxide emissions from rice-wheat rotation ecosystems in China. Plant Soil. 327:315330.

Yun, Y. D., Park, T. S., and Oh, Y. J. (1993). Establishment of Dry Seeding Cultivation Method. Annual Research Report, 1993 (Rice) National Crop Experiment Station, Suwon, Korea.

\section{How to cite this article:}

Singh, S.P., K.K. Paikra and Savita Aditya. 2019. Direct Seeded Rice: Prospects, Constraints, Opportunities and Strategies for Aerobic Rice (Oryza sativa L) in Chhattisgarh - A Review. Int.J.Curr.Microbiol.App.Sci. 8(09): 889-912. doi: https://doi.org/10.20546/ijcmas.2019.809.106 